\begin{tabular}{|c|c|}
\hline SEP $111996 \%$ ENGINEERING DATA TRANSMITTAL & Poge 1 of $\frac{1}{1}$ \\
\hline Sta, 37 & 1. EOT 618212 \\
\hline
\end{tabular}

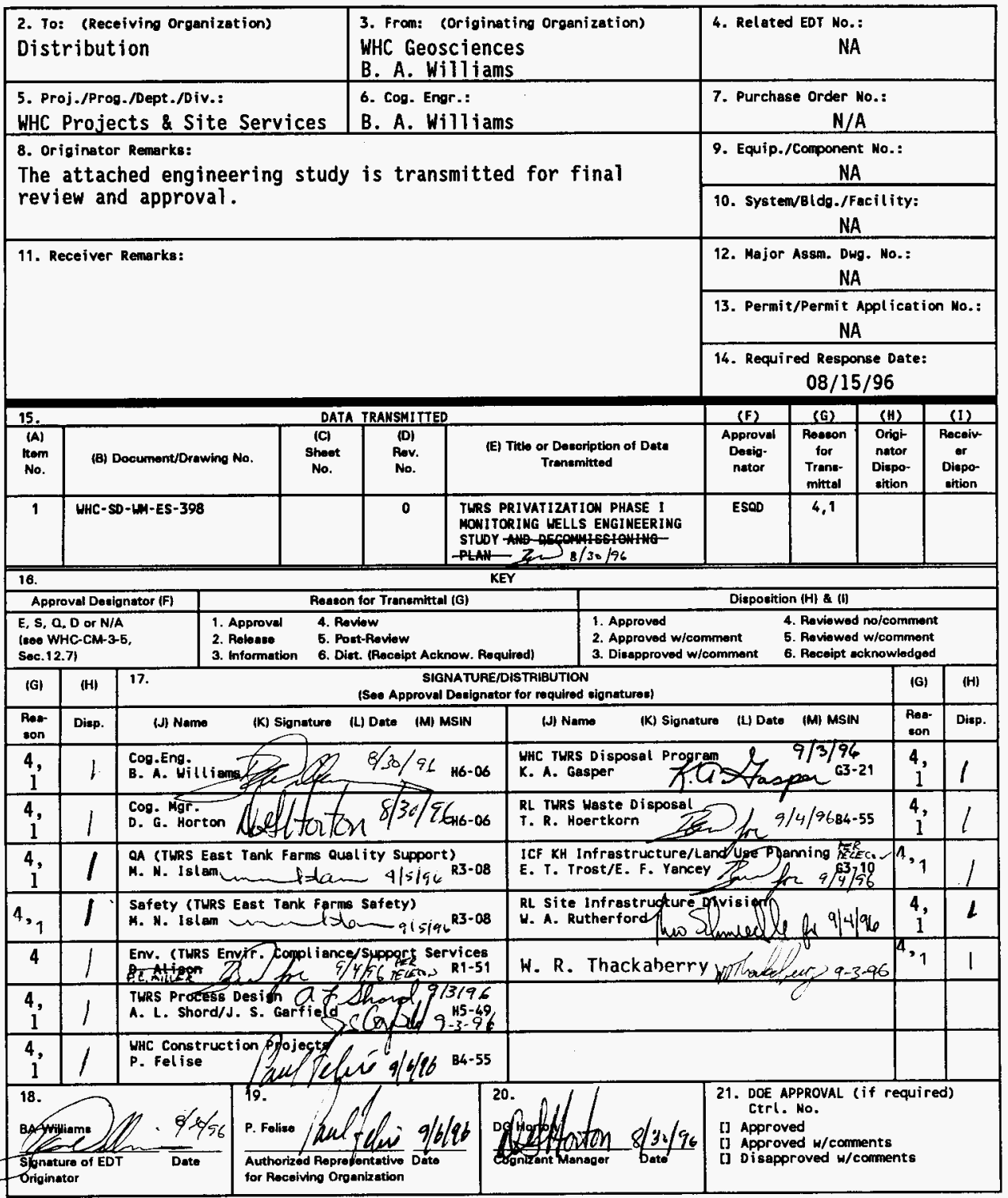




\title{
TWRS PRIVATIZATION PHASE I MONITORING WELLS ENGINEERING STUDY
}

\author{
B.A. Williams \\ Westinghouse Hanford Company, Richland, WA 99352 \\ U.S. Department of Energy Contract DE-AC06-87RL10930 \\ EDT/ECN: 618212 \\ UC: 2050EM \\ Org Code: 8 H2OO \\ Charge Code: D627B \\ B\&R Code: EW3130010 \\ Total Pages: 61
}

Key Words: TWRS PRIVATIZATION PHASE I DEMONSTRATION AREA WELLS, DECOMMISSIONED WELLS IN GROUT FACILITY, WELL USE IN TWRS PHASE I DEMONSTRATION AREA.

Abstract: This engineering study evaluates all well owners and users, the status or intended use of each we 11, regulatory programs, and any future well needs or special purpose use for wells with in the TWRS Privatization Phase I demonstration area. Based on the evaluation, the study recommends retaining 11 of the 21 total wells within the demonstration area and decommissioning four wells prior to construction activities per the Well Decommissioning Plan (WHC-SD-EN-AP-161, Rev. 0, Appendix I). Six wells were previously decommissioned.

TRADEMRK DISCLAIMER. Reference herein to any specific comercial product, process, or service by trade neme, tradenark, manufacturer, or otherwise, does not necessarily constitute or imply its endorsement, recommendation, or favoring by the United States Government or any agency thereof or its contractors or subcontractors.

Printed in the United States of America. To obtain copies of this document, contact: HHC/BCS Document Control Services, P.0. Box 1970, Mailstop H6-08, Richland Wh 99352, Phone (509) 372-2420; Fax (509) 376-4989.
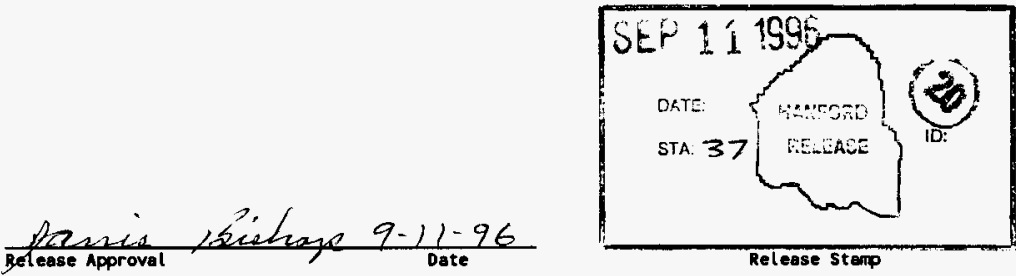

Approved for Public Release 
WHC-SD-WM-ES-398 Rev. 0

This page intentionally left blank. 


\section{CONTENTS}

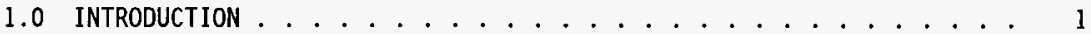

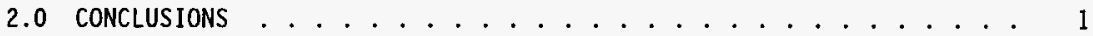

3.0 EVALUATION CRITERIA AND DQOS ............... 2

3.1 FUTURE WELL REQUIREMENTS . . . . . . . . . . . 4

3.1.1 New Program Needs ............... 4

3.1.2 Existing Program Needs . . . . . . . . . . . 5

4.0 IDENTIFICATION OF WELLS FOR DECOMMISSIONING . . . . . . . . 6

4.1 WELLS COMPROMISED BY PRIVATIZATION CONTRACTOR CONSTRUCTION

ACTIVITIES . . . . . . . . . . . . . . . . . 7

4.1.1 Compromised Wells Requirements . . .. . . . . . 8

5.0 FUTURE WELL ACCESS . . . . . . . . . . . . . . 9

6.0 STUDY SUMMARY . . . . . . . . . . . . . . . . 9

7.0 REFERENCES . . . . . . . . . . . . . . . . . . . 10

APPENDIX A TWRS PRIVATIZATION PHASE I WELL BASE MAP ......... A-1

APPENDIX B TWRS PRIVATIZATION PHASE I WELL AS-BUILT DIAGRAMS . . . . . B- B

APPENDIX C EFFICIENCY-BASED GROUNDWATER MONITORING NETWORK DESIGN FOR

THE PROPOSED ILLW STORAGE FACILITY . . . . . . . . . . . . . c-1

\section{LIST OF TABLES}

1 TWRS Phase I Privatization Area - Well Data Table .......... 3 
WHC-SD-WM-ES-398 Rev. 0

This page intentionally left blank. 


\subsection{INTRODUCTION}

This engineering study provides an evaluation of existing wells and boreholes within the selected location for the Tank Waste Remediation System (TWRS) Privatization Phase I demonstration site (Shord 1996). This evaluation is to determine which wells will remain active within the demonstration site based on regulatory, programmatic, and/or other beneficial use requirements. Wells that have no future or beneficial purpose will be decommissioned prior to TWRS Privatization Phase I construction activities to minimize liability to the U.S. Department of Energy (DOE) because of the land use changes. Twentyone wells and boreholes (we11s) exist within the identified boundary of the demonstration site (Appendix A). The wells identified for decommissioning will be abandoned according to the well decommissioning plan (Skoglie 1996). Future we11 requirements within the site include replacement wells for those wells impacted by construction activities, and/or replacements for Resource Conservation and Recovery Act of 1976 (RCRA) wells going dry.

\subsection{CONCLUSIONS}

The conclusions of this study of existing well needs within the TWRS Privatization Phase I Demonstration Site are as follows:

- Three Groundwater Programs rely on wells within the area to meet Federa1, state, or U.S. Department of Energy (DOE), Richland Operations office (RL) groundwater compliance requirements; Westinghouse Hanford Company (WHC) RCRA and Operational Monitoring (ROM), Pacific Northwest National Laboratory (PNNL) Sitewide Surveillance, Bechtel Hanford Inc. (BHI) Comprehensive

Environmental, Response, Compensation, and Liability Act of 1980 (CERCLA).

- There are a total of 21 wells within the site, 10 fulfill program compliance requirements. One other well will be retained to support a proposed new interim storage facility. Six wells have, previous to this study, been decommissioned, and four wells have been identified to be decommissioned.

- There are 9 out of the 10 program monitoring wells that meet required Washington Administrative Code (WAC), Chapter 173-160, well construction standards and do not currently pose a threat (pathway to the aquifer) to the public or the environment. Well 299-E25-25 will require either a state well construction waiver or additional surface remediation to bring it into compliance with the WAC requirements. This work will be performed by the Well Services Group.

- Decommissioning of the four orphan wells will commence after RL approval or privatization contractor turndown of the we11s, and when funding is identified. Decommissioning activities will proceed according to the decommissioning plan (Skoglie 1996). 
- New well requirements within the demonstration area such as those that might support the RCRA (proposed Immobilized Low-Level Waste [ILLW] Storage Facility), site characterization (TWRS Phase II site assessment), and for replacement of wells impacted by planned privatization contractor construction activity will be addressed in separate plans, permits, as identified by the ROM Program.

\subsection{EVALUATION CRITERIA AND DQOS}

Well data quality objectives (DQOS) are defined by the individual user for the program they support and will not be reevaluated in this study. All active wells must meet the minimum WAC 173-160 construction requirements (or State Waiver) in order to maintain protection (minimize potential for contamination) to the environment and provide representative data. The RCRA program has the most restrictive data quality standards. Hanford Site programs that currently use wells in the TWRS Privatization Phase I area include; 1) the WHC ROM Program (this program also includes Site water level mapping and vadose monitoring), 2) The PNNL Sitewide Surveillance Program, and 3) the BHI CERCLA Program.

Table 1 provides a list of all wells located within the defined boundary of the TWRS Phase I demonstration siting (former Grout Treatment Facility [GTF]). Several well databases were queried for the compilation of this table including Hanford Wells (PNL-8800), Hanford Well Custodians (WHC-SD-EN-DP-071, Rev. 1), RCRA Borehole Data Packages for the GTF (WHC-SD-EN-DP-085, Rev. 0), and GeoDAT/Paradox (WHC proprietary electronic database). In addition to database queries, each program was contacted and provided input to the table.

Each well has an assigned custodian responsible for its maintenance and eventual decommissioning. The table identifies the current users of each well and summarizes the well type, location in Hanford Plant and Lambert coordinates, borehole total depth, well completion date, and perforations or screen interval and the approximate remaining saturated interval. Well asbuilt diagrams are attached as Appendix B. These diagrams provide useful information to various programs including the existing groundwater sampling intervals, subsurface geology, and potential contaminant pathways to the environment.

Each groundwater monitoring program has specific criteria and requirements for well use and this study assumes that the wells are suitable to meet those intended program requirements. Therefore, this study will not reevaluate this aspect of well use. Instead, this study will evaluate ways to reduce the number of wells required by integrating program needs and combining well use.

Existing wells are also evaluated to determine if they pose an obstacle or impact planned facility construction for the site study. Wells that pose potential construction obstacles will be evaluated to determine if other existing wells could fulfill the users DQOS or if new wells need to be installed. 


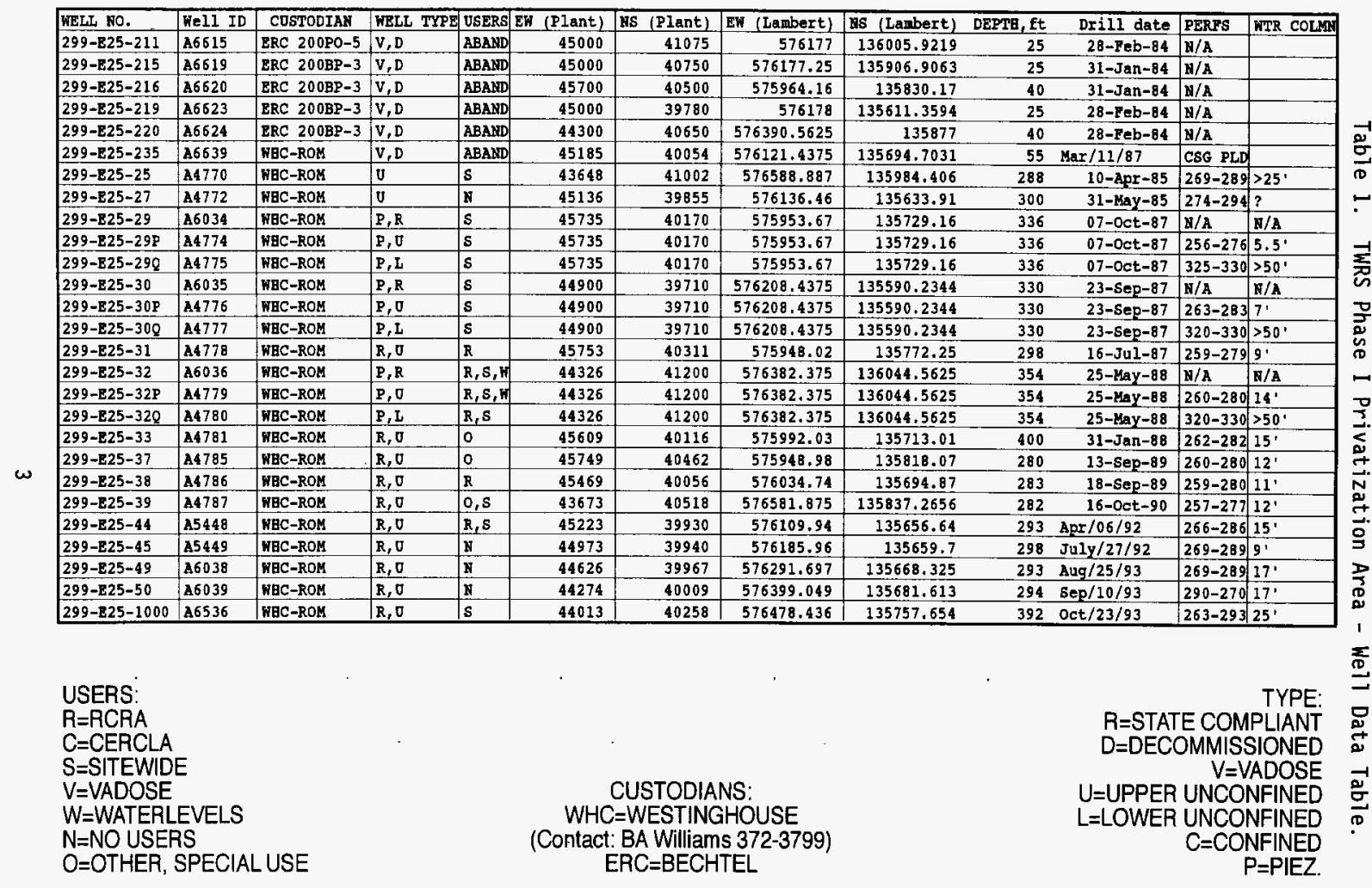


WHC-SD-WM-ES-398 Rev. 0

\subsection{FUTURE WELL REQUIREMENTS}

This study evaluates all future well use options prior to decommissioning to ensure the most efficient use of resources. Groundwater well needs are based on two categories; 1) Supply, and 2) Resource Protection.

1) Water supply wells will not be required for this area because the upper unconfined groundwater already contains many contaminants and will not meet water quality standards. The installation of water supply wells into deeper noncontaminated aquifers increases the risk of cross contamination from the shallow aquifer and is not recommended in this area. Water is readily available from several existing sources within the 200 Area, which can be accessed via pipeline.

2) Resource protection wells are installed to detect contaminants from a facility that may pose a threat to the public and/or the environment. In addition, these wells are used to assess groundwater conditions and cleanup activities ongoing throughout the 200 Area Hanford Plateau.

Future groundwater well requirements within the TWRS Privatization Area fall into the resource protection well category and will be based on new and existing program needs.

\subsubsection{New Program Needs}

New facilities that treat, store, or dispose dangerous or hazardous waste must meet RCRA or state groundwater monitoring requirements. Identified new programs within the TWRS Privatization Phase I Demonstration Site are listed below:

1) Privatization Contractor (PC) Facility(ies) - New facility groundwater monitoring needs will be defined in the RCRA operating permit requirements, which must be negotiated between the regulators and the PC. Initially, based on planned activities, this facility is not expected to require groundwater monitoring for treatment, storage, or disposal under the RCRA. Prior to the abandonment of any existing wells in the construction area, the PC will be given the option to procure these wells to fulfill anticipated needs or requirements. The $P C$ will be responsible for all its individual well needs within the area or it may rely on the preexisting well database accessed through the Hanford Environmental Information System (HEIS).

2) ILLW Interim Storage Facility - Groundwater monitoring may be required at the former Grout Facility (now called ILLW Interim Storage Facility), which is located on the west side of the Phase I Privatization area (Appendix A). This facility has been defined as the best alternative proposed for an interim storage facility. It is being evaluated to receive and store the PC's ILLW product starting in 2002. TWRS ILLW Interim Storage Facility (subproject OOL-EEW-465) is intended to provide storage under the direction of 
DOE, as proposed in Burbank (1996) a predecisional draft that outlines alternatives for ILLW interim storage architecture. Currently, the existing wells surrounding the ILLW Interim Storage Facility meet groundwater compliance requirements with the RCRA regulation for a land disposal facility (DOE-RL 1990). Facility groundwater monitoring is adequate for the current groundwater flow direction and provides a $>95 \%$ coverage for leak detection based on Monitoring Efficiency Model (MEMO)(Appendix C) resuits. Wells identified in this engineering study for decommissioning will not compromise RCRA groundwater compliance at the ILLW Interim Storage Facility. Long-range monitoring requirements may require future replacement wells for some wells going dry as the water table declines (e.g., 299-E25-38). This evaluation will be detailed in the appropriate RCRA groundwater monitoring plan as required by the regulations, and the Site Part-B Permit and is not a part of this study.

3) TWRS Phase II Performance Assessment - Disposal of the PC's ILLW product in the TWRS ILLW Interim Storage Facility (former GTF) will require subsurface characterization. This data wiTl be used to support the performance assessment of the facility. To support this assessment, one new groundwater monitoring well will be installed to characterize the vadose and aquifer system. Planning for this borehole, including the location, are forthcoming (Reidel 1995) and not subject of this engineering study.

\subsubsection{Existing Progran Needs}

Individual groundwater monitoring programs must maintain groundwater compliance for specific groundwater conditions. Known changes occurring within the hydrogeologic system (aquifer) include declining water levels, changing flow directions, and changing contaminant plume concentrations and migration pathways. The Hanford Sitewide Groundwater Remediation Strategy/Groundwater Contaminant Predictions (BHI-00469) provides a Site groundwater and contaminant flow model, which has been used to evaluate these changes and determine, as practicable, the magnitude and extent of the change. Based on these model predictions an assessment of network well requirements has been completed for outer years. These changes could require additional new well installations to provide adequate monitoring coverage.

Out of 21 total wells within the Phase I area, 10 have been identified as active wells, which should be retained to support State or DOE groundwater monitoring requirements. With the exception of well 299-E25-25 all the wells meet current State requirements for resource protection wells. This well requires surface protection (pad, posts, and a permanent well identification number) to bring it into compliance with State well requirements. Well remediation (or a request for a State well construction waiver) will be scheduled and performed by WHC Well Services.

The WHC ROM program utilizes six wells within the area to ascertain groundwater flow, detect and assess groundwater contamination, and monitor declining water levels in the upper unconfined aquifer. Under the RCRA, there are four facilities with two separate groundwater networks, the 216-A-29 
Ditch, and the combined 216-A36-B, 216-A10, and 216-A37-1 Cribs (P1utoniumUranium Extraction [PUREX] Cribs) network, which are located proximal to the area and rely on three wells within the privatization area (Appendix $A$ ). In addition, the Operational program relies on three different wells to monitor groundwater at the 216-A-30 and 216-A37-2 Cribs.

The PNNL Sitewide Surveillance program provides regional groundwater plume mapping for the entire Hanford Site (e.g., PNL-10698) in support of DOE-RL Order 5400.1 . This program relies on six wells within the study area, two of which are ROM wells, to fulfill its program requirements (Appendix A). No additional well requirements are anticipated for this area in the future.

The BHI CERCLA program is responsible for groundwater remediation/cleanup under the P0-1 Operable Unit (OU), which encompasses the study area and currently utilizes data results from the ROM and Sitewide Programs to supplement CERCLA program monitoring and provide groundwater qual ity determinations. BHI has indicated no additional future well requirements within the study area.

Review of modeled and expected changes to the aquifer system does not indicate any immediate or future needs for additional wells within the area to maintain RCRA compliance. Modeled results indicate that the maximum water table decline in the area will be approximately $3 \mathrm{~m}$ (9 ft) over the next 20 years. Based on this information the wells selected for monitoring have an adequate water column for sampling through this time period. If any of the wells do go dry they will be evaluated for replacement by the appropriate well custodian and documented in the programs groundwater monitoring plan. Groundwater flow over. the next 20 years is predicted to change only slightly from the current flow direction, toward the southwest, to a more southeast flow. Existing wells are adequately located to account for this change and no new well requirements are anticipated. The plume simulation model indicates that the groundwater contaminant plumes preferential flow path does not significantly change direction over the next 20 years. If contaminants do begin to migrate toward the southeast they will be monitored by existing wells located on the eastern side of the area.

Based on the preceding evaluation of the existing wells, only one new well has been identified. This well is in support of the ILLW Storage Facility performance assessment. The location, drilling and construction of this we 11 will be completed per the requirements of the characterization documentation (Reidel 1995).

No other new wel1 needs within the TWRS Privatization Phase I Demonstration Site are envisioned for the future.

\subsection{IDENTIFICATION OF WELLS FOR DECOMMISSIONING}

The 21 existing wells are divided into four categories to aid in consolidating well usage (Appendix A) and identify candidates for decommissioning: 
Category 1 - Decommissioned Wells - This category defines six existing boreholes which have, previous to this study, al ready been decommissioned. The wells are 299-E25-211, $-215,-216,-219,-220$, and -235 . These wells are listed in the table and the locations are provided for reference to allow the construction contractor the ability to locate them during construction activities as necessary.

Category 2 - Candidate Decommission Wells - There are four existing boreholes identified with no use and are considered candidates for decommissioning. The wells are 299-E25-27, $-45,-49,-50$ (Appendix A) and are identified in Table 1 by an "N" under the USER column. A Well Decommissioning Plan (Skoglie 1996), provides specific decommissioning requirements for these wells.

Category 3 - Active Wells - Eleven total wells will be retained as active wells. Ten wells have been identified that support program requirements as summarized in Section 3.1.2. In addition, one well (former GIF RCRA well 299-E25-38) will remain active to support future well needs at the proposed ILLW Storage Facility. The wells are identified in Table 1. Well 299-E25-38, can be decommissioned (and is identified with a hold point in the decommissioning plan [Skoglie, 1996] pending further evaluation) if the ILLW facility does not require RCRA monitoring.

Category 4 - Compromised Wells - Four of the eleven Category 3 wells identified may be compromised by impacts from future privatization construction activities. The wells are identified as 299-E25-25, -32,-39, and -1000 .

\subsection{WELLS COMPRONISED BY PRIVATIZATION CONTRACTOR CONSTRUCTION ACTIVITIES}

Results of the evaluation of the category 4 wells, completed by the three groundwater programs (RCRA, CERCLA, and Sitewide), are described in this section. Based on a review of the proposed construction activities for the Phase I privatization four wells may be compromised. Because the proposed construction area is still being studied and defined (TWRS Phase I Privatization Site Development Engineering Study), the exact number of category four wells that will be impacted is not known. The four wells, 299E25-25, $-32,-39$, and -1000 , have been prioritized according to the existing program(s) importance, i.e., based on program DQOs, spacial location, and the remaining saturated interval within the wells. This prioritization will assist in subsequently determining the need for, and replacement of, the impacted wells.

Category 4 wells are prioritized as follows:

Priority 1 - We11 299-E25-32 - Groundwater results support all three programs (RCRA, CERCLA, Sitewide). This well has added value because it is completed in two intervals (piezometer) within the upper aquifer and thus provides information about the vertical gradients, and radiochemical distribution across the interval. It is one of only a handful of wells at Hanford which provide this type of access to the aquifer. The location of this well is key to understanding the impacts and effects of B-Pond recharge to the aquifer, the decline of the artificial groundwater mound, and changes to the flow system. RCRA utilizes this well as an 
upgradient location for several facilities. This well also has a good historical groundwater database and declining groundwater will not impact the ability to sample this well.

Priority 2 - Well 299-E25-25 - Utilized by the PNNL Sitewide Surveillance program. This well's location is also key to tracking the $B-P o n d$ mound decline and changing groundwater conditions. Declining groundwater will not impact the ability to sample this well.

Well 299-E25-1000 - Utilized by the PNNL program. This is the newest of all the wells within the area and is in a location that supports the evaluation and interpretation of regional groundwater conditions. Declining groundwater will not impact the ability to sample this well.

Priority 3 - Well 299-E25-39 - Utilized by the PNNL program. This well is also in a good location for evaluating the B-pond mound decline and effects on regional groundwater conditions. Declining groundwater will impact the ability to sample this well. Less than $8 \mathrm{ft}$ of water is left in the screen and projected declines indicate that this well will go dry in a few years.

\subsubsection{Compromised We11s Requirements}

The Priority 1 well, E25-32, will require a replacement well installed further east if the vendors construction activity requires this well be decommissioned. Decommissioning costs are minimal (approximately $\$ 5,000 /$ wel1) and a replacement well can be installed for approximately $\$ 75,000$. Well planning, borehole drilling, and actual construction will require approximately 3 months.

Priority 2 wells will require one replacement if either; 1) 299-E25-1000 or, 2) both wells (299-E25-1000 and 299-E25-25) are decommissioned. If only 299-E25-25 is decommissioned, well 299-E25-1000 may be substituted.

The Priority 3 well (299-E25-39) can be decommissioned and will not require a replacement. Current plans are to systematically decommission the well when it can no longer be sampled.

Preliminary indications from the ongoing TWRS Privatization Phase I infrastructure project definition engineering studies indicate only one well (299-E25-32) with a high probability of being impacted. Based on the Priority 1 classification this well will require a replacement if it must be decommissioned. The other three compromised wells (priority 2 and 3 ) are located far enough east of the proposed construction zone that they would probably pose no problem. Easements will have to be established around the compromised wells to maintain access for sampling and provide protection from future 1 and use activities. If the compromised wells turn out to impact the $P C ' s$ construction then replacement of the wells will be required per this section. 
WHC-SD-WM-ES-398 Rev. 0

\subsection{FUTURE NELL ACCESS}

Per the recommendations of this study, all planned construction activities shall be engineered to allow continued access to the active wells for the purpose of program groundwater sampling, well maintenance, or other scheduled work. Any contractor wishing to access wells will be required to acquire approval from the well custodian as identified in Table 1.

\subsection{STUDY SUMMARY}

There are a total of 21 wells within the demonstration area, 10 fulfill RCRA, CERCLA, or Sitewide groundwater program compliance requirements and DQ0s. Well 299-E25-25 will require surface remediation [or a state waiver] to bring it into compliance with the WAC regulations. Six wells have, previous to this study, been decommissioned, and four wells have been identified to be decommissioned per the decommissioning plan (Skoglie 1996).

New well requirements within the demonstration area include; one new characterization well installed in support of and funded by the ILLW Storage Facility and, as will be determined, possible replacements for the compromised wells. It is recommended that discussions be held with the PC's prior to construction activities to negotiate a work-around for the compromised wells to minimize well decommissioning and maintain groundwater data continuity. Any well that resides within a parcel assigned to the $\mathrm{PC}(\mathrm{s})$ will require an easement for vehicle access and for sampling and well servicing.

If additional RCRA groundwater monitoring wells within the TWRS Phase I Demonstration Site are required by other programs they will be addressed separately by the WHC ROM Program in the appropriate RCRA groundwater monitoring plan as required by the facility permit. The location of the additional wells will need to be negotiated with the PC's.

The PC(s) should have the opportunity to take custody of any of the targeted category 2 wells (prior to decommissioning) to fulfill any of their future well needs. These well needs will be determined in operating permits (which will determine State groundwater monitoring requirements).

There are two options for funding category 2 well decommissioning.

Option 1 - Funding by TWRS to decommission the category 2 wells (approximately $\$ 20,000$ \$5,000/wel1). WHC Well Services will perform the decommissioning work to meet the TWRS schedule.

Option 2 - A well decommissioning program exists under the WHC Well Services Group which budgets (under the ROM program) and resource loads tasks to systematically define and decommission up to 50 wells per year. The wells identified in category 2 would have to be added to the Well Services decommissioning 1 ist and prioritized, accordingly, based on criteria defined in the well decommissioning plan (Skoglie, 1996). The wells would be 
scheduled for decommissioning under the Well Services program schedule and the work completed by the group. Currently, based on the well decommissioning program, the Category 2 wells would be considered low priority and would probably not be scheduled for decommissioning in the FY 1998 time frame required to support the TWRS Privatization Phase I site development work. Further evaluation of this option relative to decommissioning the Category 2 wells within the TWRS Privatization site development schedule needs to be completed to finalize the funding scenario.

\subsection{REFERENCES}

Burbank, D. A., 1996, Alternatives Generation and Analysis Report for Immobilized Low Level Interim Storage Architecture, WHC-SD-W465-AGA-001, Rev A.- PREDECISIONAL DRAFT, Westinghouse Hanford Company, Richland, Washington.

Shord, A. L., 1996, Tank Waste Remediation System Privatization Phase I Site Evaluation Report, WHC-SD-WM-SE-023, Rev. 0-A, Westinghouse Hanford Company, Richland, Washington.

Resource Conservation and Recovery Act of 1976, 42 USC 6901, et seq.

WAC 173-160, 1990, Washington Administrative Code (WAC), Chapter 173-160, Minimum Standards For Construction and Maintenance of Wells, State of Washington, Department of Ecology.

WHC-SD-EN-DP-071, Rev. 1, 1995, Hanford Well Custodians, Westinghouse Hanford Company, Richland, Washington.

WHC-SD-EN-DP-085, Rev.0, 1994, 1993 Borehole Completion Data Package, Grout Treatment Facility Wells 299-E25-49, 299-E25-50, 299-E25-1000, Westinghouse Hanford Company, Richland, Washington.

BHI-00469, Rev. 0, 1996, Hanford Sitewide Groundwater Remediation Strategy/Groundwater Contaminant Predications, Bechtel Hanford Company, Richland, Washington.

PNL-8800, Hanford Wells, Pacific NorthWest National Laboratory, Richland, Washington.

PNL-10698, 1995, Hanford Site Ground-Water Monitoring for 1994, Pacific Northwest National Laboratory, Richland, Washington.

DOE-RL, 1990, Grout Treatment Facility Dangerous Waste Permit Application, DOE/RL 88-27, Rev. 1, U.S. Department of Ecology, Richland Field office, Richland, Washington.

Reidel, S. P., 1995, Characterization Plan for the Proposed TWRS Treatment Complex, WHC-SD-WM-PLN-109, Rev. 0, Westinghouse Hanford Company, Richland, Washington. 
Skoglie, D. E., 1996, Well Decommissioning Plan, WHC-SD-EN-AP-161, REV 0, Draft Appendix I, Fitness for Use Evaluation Recommendations for Hanford Site We77s, Engineering Change Notice \# 708153, Westinghouse Hanford Company, Richland, Washington.

Mercer, R. B., C. R. Wilson ${ }^{4}$, C. M. Einberger ${ }^{1}$, and R. L. Jackson, 1991, Efficiency-Based Groundwater Monitoring Network Design for Hazardous Waste Sites.

${ }^{1}$ Golder Associates, Inc., Redmond, Washington 98052. 
WHC-SD-WM-ES-398 Rev. 0

APPENDIX A

TWRS PRIVATIZATION PHASE I

WELL BASE MAP 
WHC-SD-WM-ES-398 Rev. 0

This page intentionally left blank.

A-2 
WHC-SD-WM-ES-398 Rev. 0

APPENDIX B

TWRS PRIVATIZATION PHASE I

WELL AS-BUILT DIAGRAMS

B-1 
WHC-SD-WM-ES-398 Rev. 0

This page intentionally left blank.

B-2 


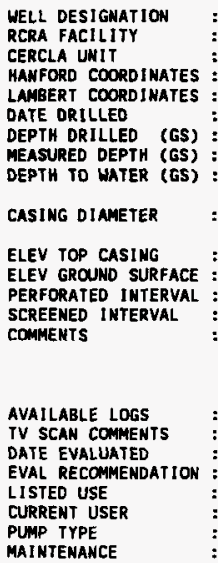

299-E25- 25

Not documented

200 Aggregite Ares Menogenent Study

N 41,001.6 H $43,648.4$ [18Jul85]

N 446,192 E 2,251,572 [HANCONV]

Apr 85

288-ft

Not documented

263-ft, Apr 85:

263.9-ft, 10 Jung3

8-in, carbon steel, 0w150-ft:

6-in, carbon steel, $+2.74 \mathrm{~m} 253-\mathrm{ft}$

$669.42-\mathrm{ft}$, [18 Jul85]

Not documented

8 -in casing, $0+150$.

269-289-ft, 6 -in \#10 slot stainless steet

FIELD INSPECTION, 27 AUG93,

Carbon steel casings. Capped and locked

No pad, posts or permanent ident ification.

Not in radiation zone.

Geologist

Not applicable

Not applicable

Not applicable

Grout semiannual water level measurenent, 01Jun85-10Jun93, HHC ES\&M w/I monitoring and RCRA sempling

Hydrostar 


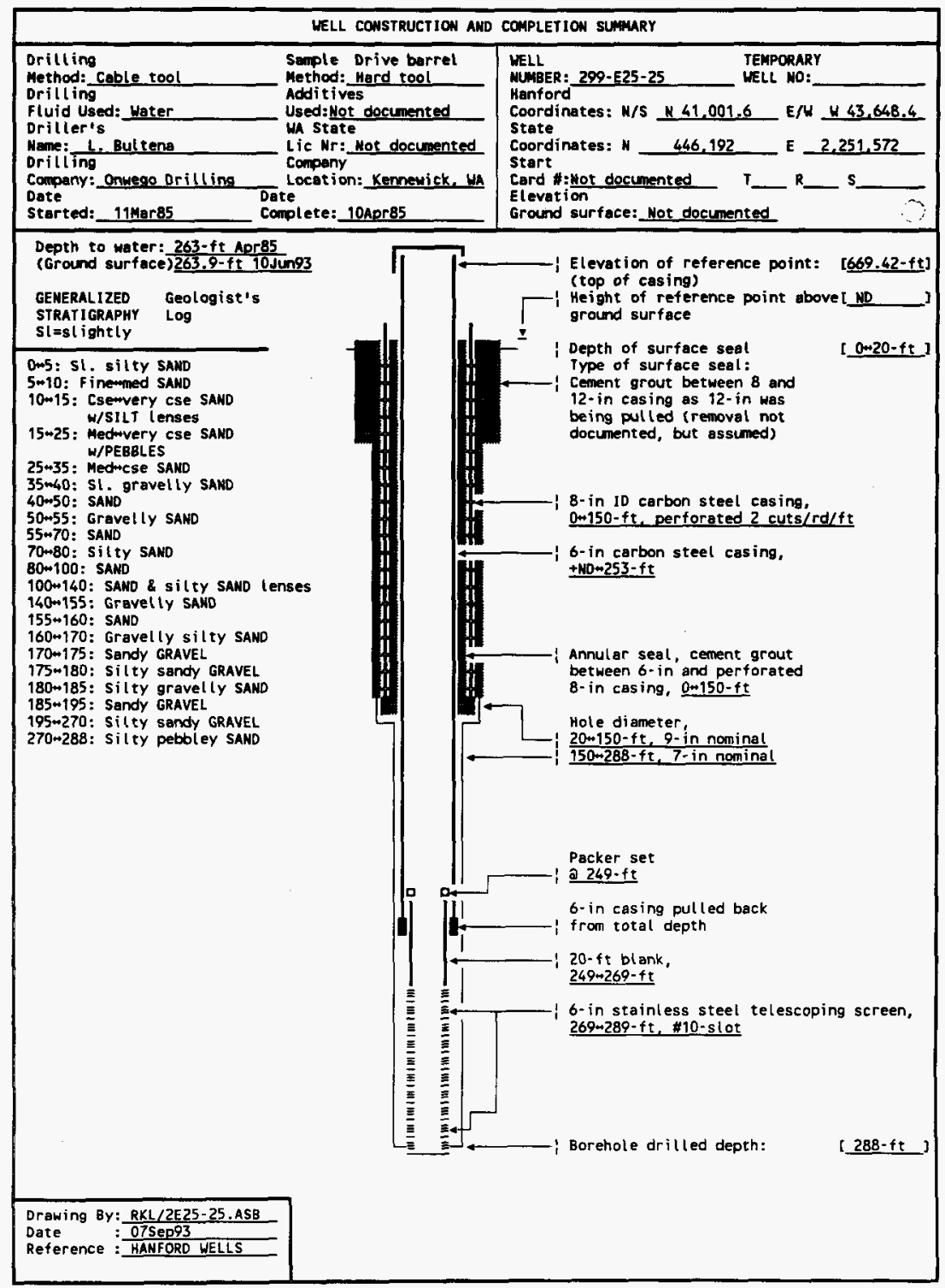




\section{SUMMARY OF CONSTRUCTION DATA AND FIELD OBSERVATIONS}

RESOURCE PROTECTION WELL - 299-E25-27

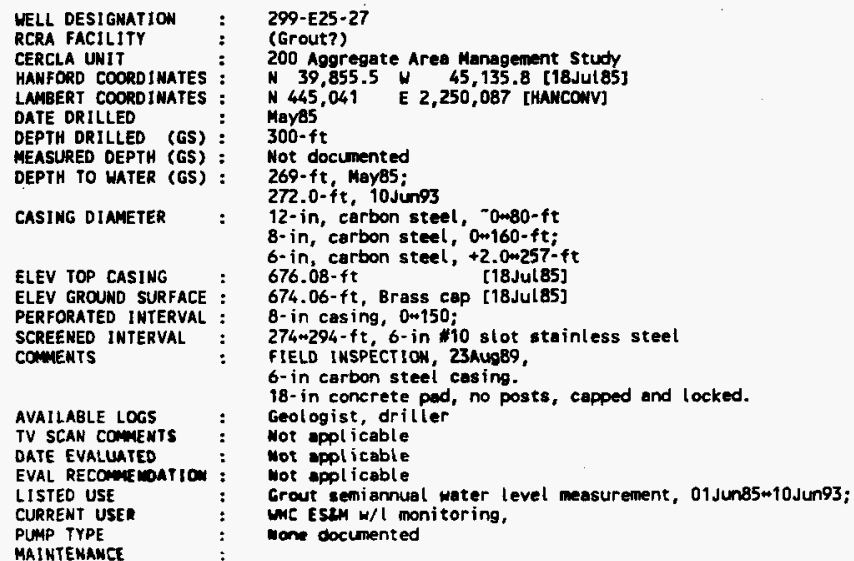




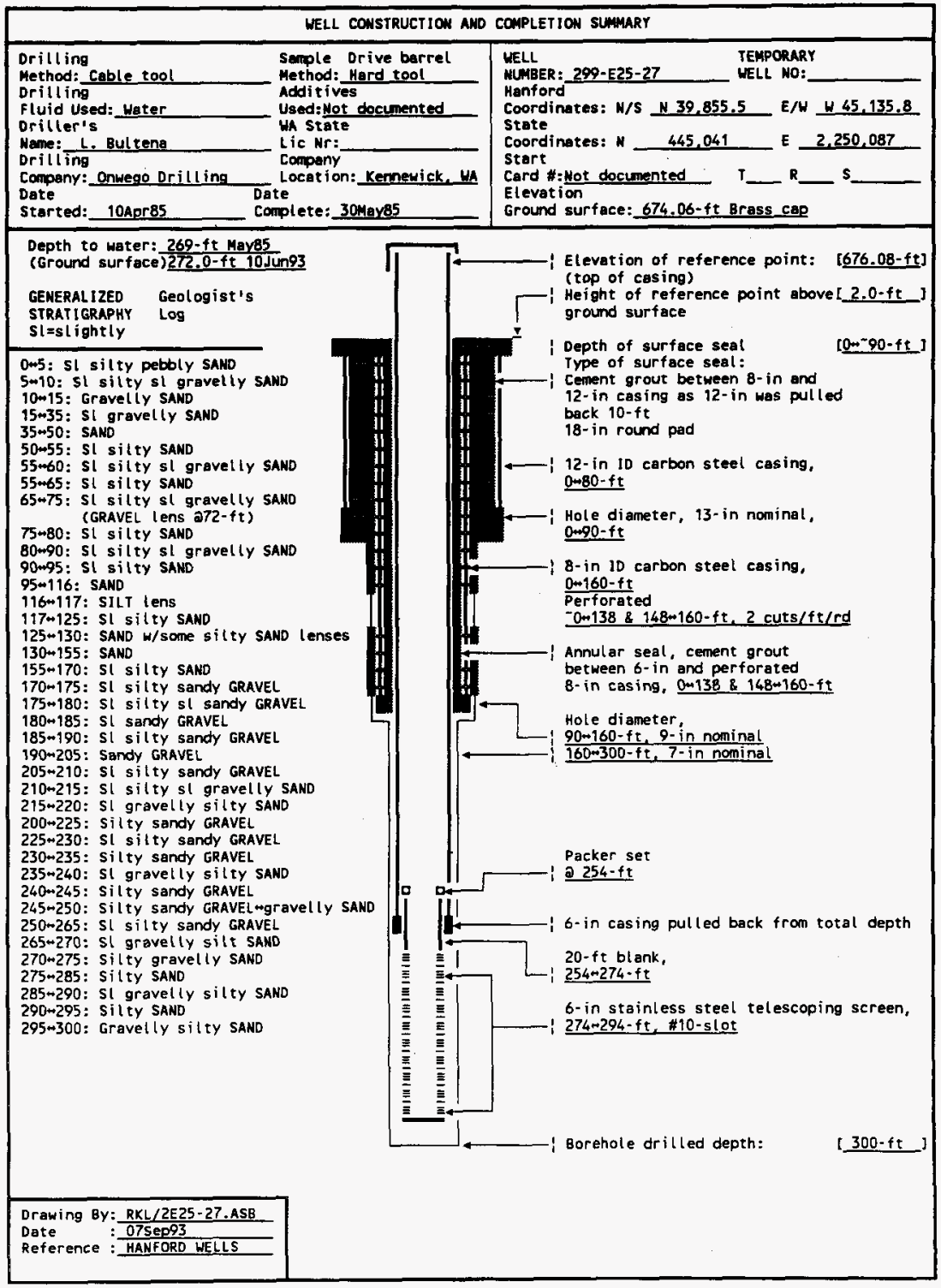




\section{SUMMARY OF CONSTRUCTION DATA AND FIELD OBSERVATIONS RESOURCE PROTECTION WELL - 299-E25-29}

WELL DESIGNATION
RCRA FACILITY
CERCLA UNIT
MANFORD COOROINATES
LAMBERT COORDINATES
DATE DRILLED
DEPTH DRILLED (GS)
MEASURED DEPTH (GS)
DEPTH TO WATER (GS)
CASING DIAMETER
ELEV TOP CASING
ELEV GROUND SURFACE :
PERFORATED INTERVAL
SCREEMED INTERVAL
COMNENTS

AVAILABLE LOGS
TV SCAN COMMENTS
DATE EVALUATED
EVAL RECOMMENDAIION :
LISIED USE
CURRENT USER
PUMP TYPE
MAINTENANCE

299-E25-29

Grout

200 Aggregate Aree Manegenent study

N 40,170 H 45,735

N 445,355 E $2,249,487$
OctB7

$330-\mathrm{ft}$

$328.8-\mathrm{ft}, 0-27$ Aug93

Not documented, oct87;

(P) $=270.1-\mathrm{ft}$, joJung3,

(O) $=269.7-\mathrm{ft}, 10 \mathrm{Jun} 93$

$12-$ in carbon steel, $+0.80-3.5-\mathrm{ft}$;

$2-i n$, stainless steel, +0.7 $256.5 \cdot \mathrm{ft},(P)$;

2 -in, stainless steel, $+0.7-325.0-\mathrm{ft},(Q)$

673.06-ft, (12-in casing) [27Mar92-NGVD'29]

672.29-ft, Bress cap [27Mar92-HGVD'29]

Not applicable

p - 2-in, 256.5+276.5- $\mathrm{ft}$, stainless steel, slot not documented

a - 2-in, 325w330-ft, stainless steel, slot not docunented

FIELD IMSPECTION, 27Aug93:

12-in carbon steel protective casing, 2 ea 2 -in stainless steel piezoneters. $4-\mathrm{ft}$ by $4-\mathrm{ft}$ concrete ped, 4 posts, 1 removable.

Capped and locked, brass cep in ped with well 10 .

Not in radiation zone.

Geologist

Not appl icable

Not appl icable

Not apolicable

Grout quarterly water level measurenent, (P) 010ec89-10Jung3

(O) 01Dec89-10 Jun93;

WHC ES\&M $W / 1$ monitoring and RCRA sampling,

PNL sitewide sampling 93

Hydrostar (P) 


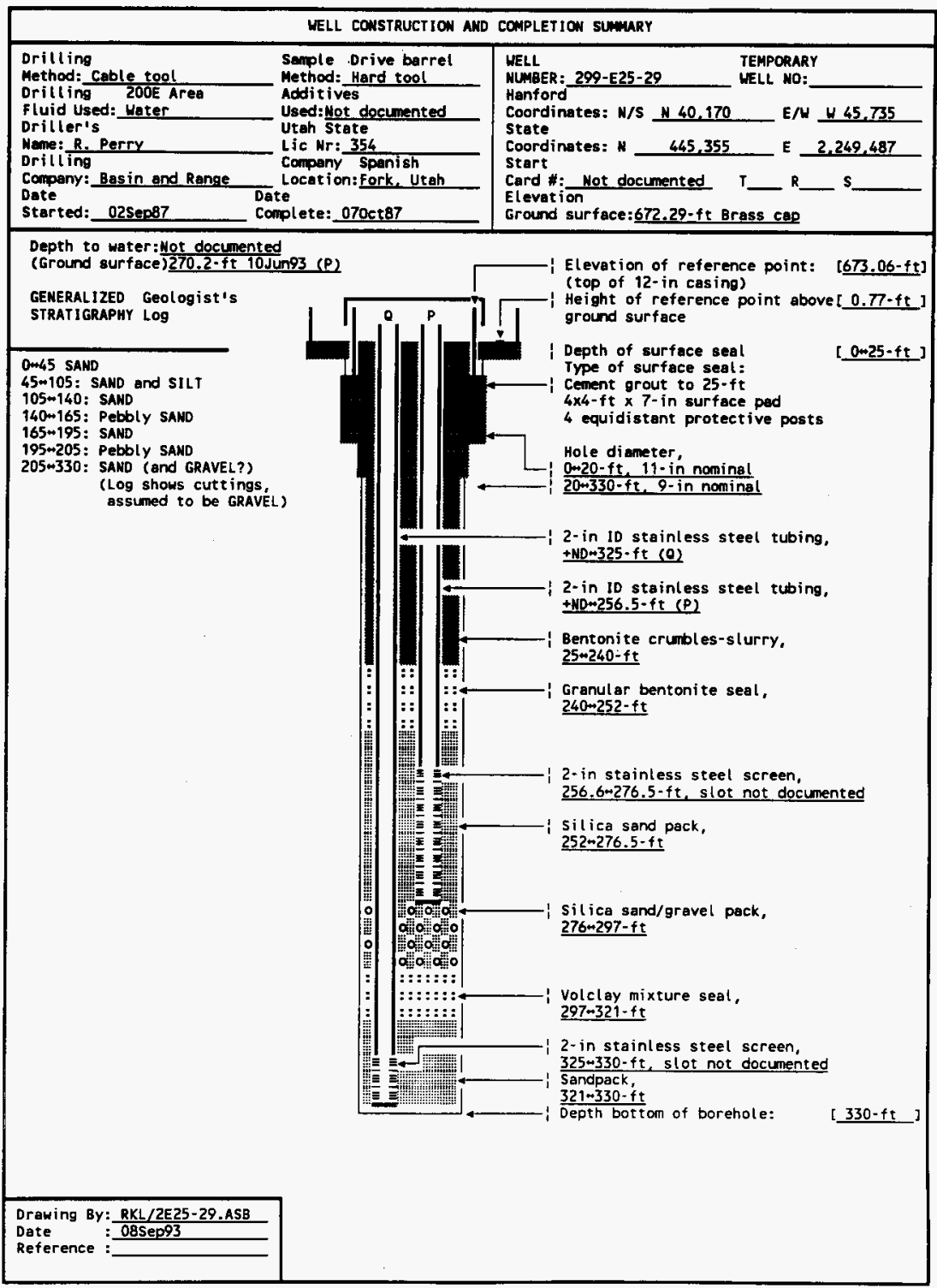




\section{SUMMARY OF CONSTRUCTION DATA AND FIELD OBSERVATIONS RESOURCE PROTECTION WELL - 299-E25-30}

WELL DESIGNATION RCRA FACILITY

CERCLA UNIT

HANFORD COORDIMATES

LAMBERT COORDIMATES :

DATE DRILLED

DEPTH DRILLED (GS) :

MEASURED DEPTH (GS) :

DEPTH TO WATER (GS) :

CASIMG DIAMETER

ELEV TOP CASING

ELEV GROUND SURFACE :

PERFORATED INTERVAL :

SCREEMED INTERVAL

COMNENTS

AVAILABLE LOGS

TV SCAN COMAENTS

DATE EVALUATED

EVAL RECOMMENDATION :

LISTED USE

CURRENT USER

PUMP IYPE

MAINTENANCE
299-E25-30

Grout

200 Aggregate Area Management Study

N 39,710 W 44,900

N 444,897 E 2,250,323

0et87

330-ft

Not documented

271-ft, 0er87;

$276.0-\mathrm{ft}, 10$ Jung3 (a)

12-in carbon steel, +0.3-3.5-ft:

2-in, stainless stél, $+0.3+263.5-\mathrm{ft},(P)$;

$2 \cdot$ in, stainless steel, $+0.0-325.0-\mathrm{ft}$, (Q)

678.15-ft (12-in casing)

-677.9-ft, Estimated

Not applicable

P - 256.5-276.5- $\mathrm{tt}, 2-$ in stainless steel, $\$ 20$ slot,

- - 325-330-ft, 2-in stainless steel, \#20 slot,

FIELD INSPECTION, 20Jan92;

Stainless steel piezoneter tubing, 12-in protective casing.

4- $\mathrm{ft}$ by $4-\mathrm{ft}$ concrete pad, 4 posts, 1 removable

capped and locked, brass cap in ped with well 10 .

Geologist

Not applicable

Mot applicable

Not applicable

Grout quarterly water level measurement, (P) 01Jun91, then uncal ibrated transducer

Grout semiannual water level measurement, 0) $010 e c 89+10$ Jung3

WHC ESBM W/L monitoring,

PUL si tewide sampling 93

Hydrostar (P) 


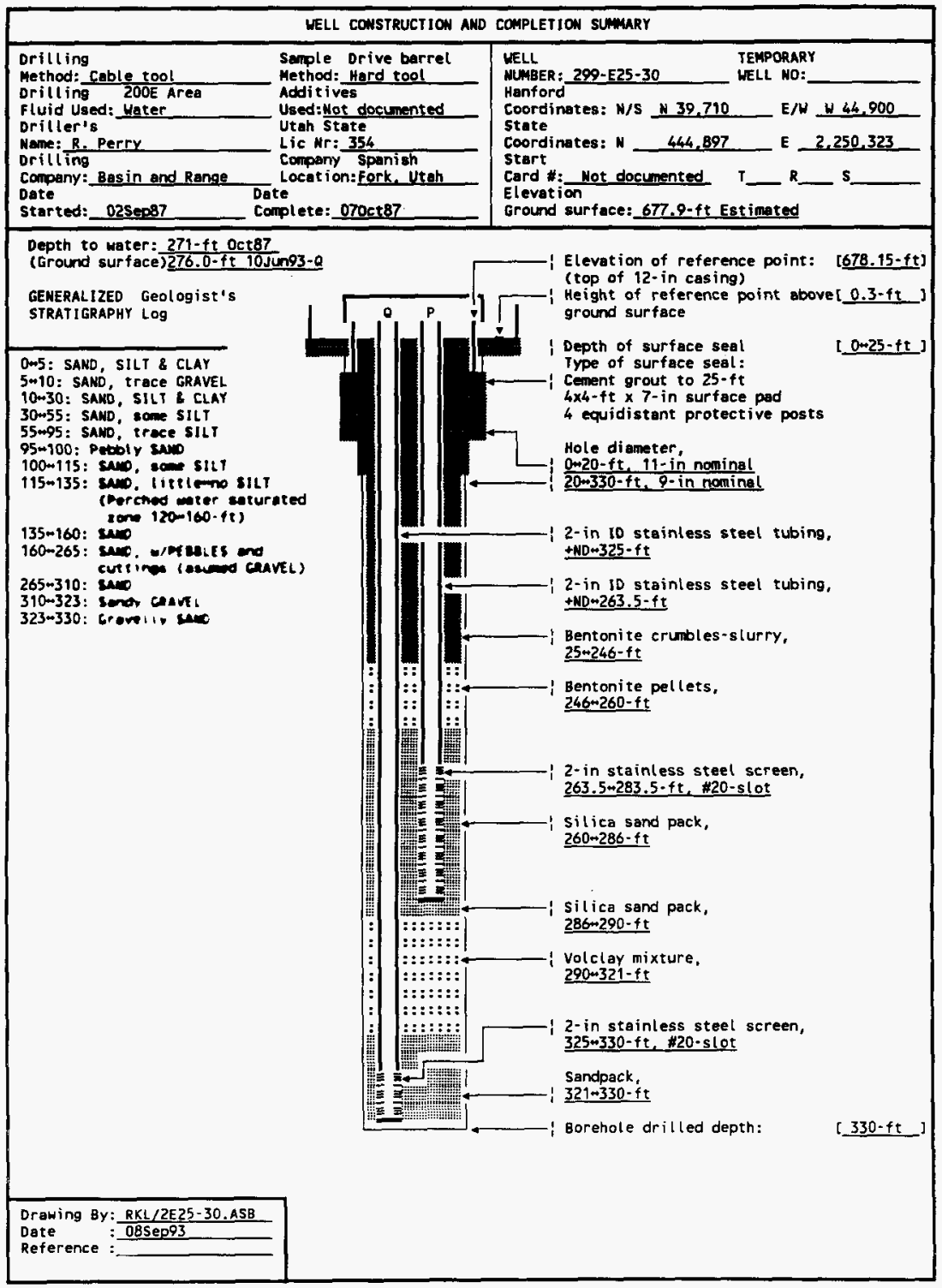


SUMMARY OF CONSTRUCTION DATA AND FIELD OBSERVATIONS

RESOURCE PROTECTION WELL - 299-E25-31

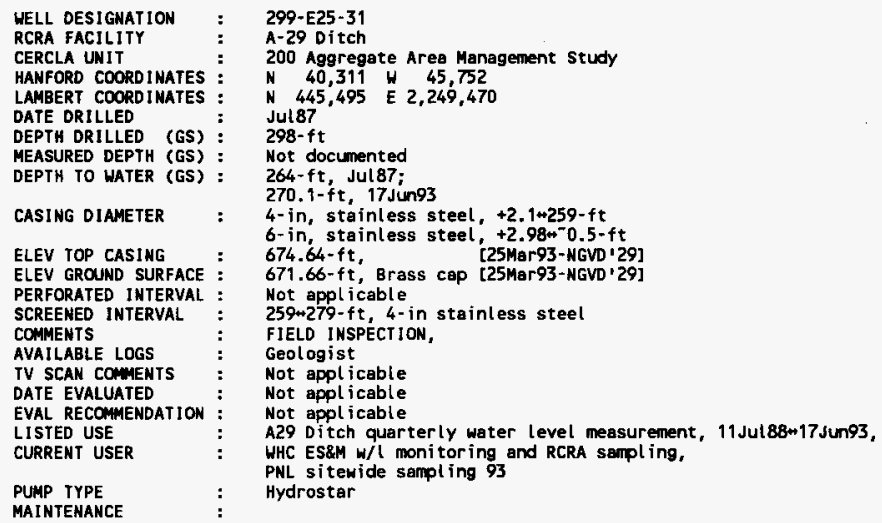




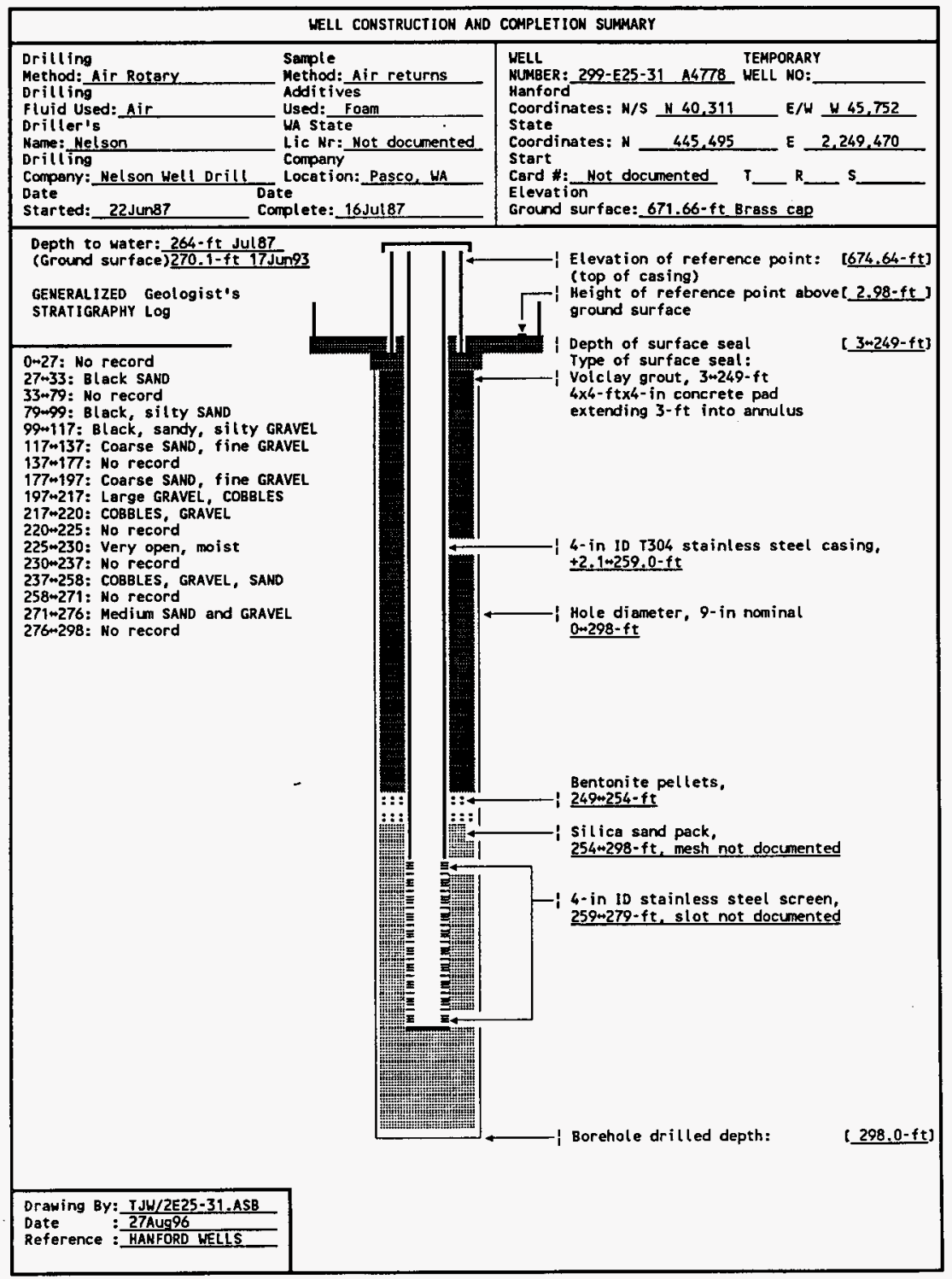




\section{SUMMARY OF CONSTRUCTION DATA AND FIELD OBSERVATIONS RESOURCE PROTECTION WELL - 299-E25-32}

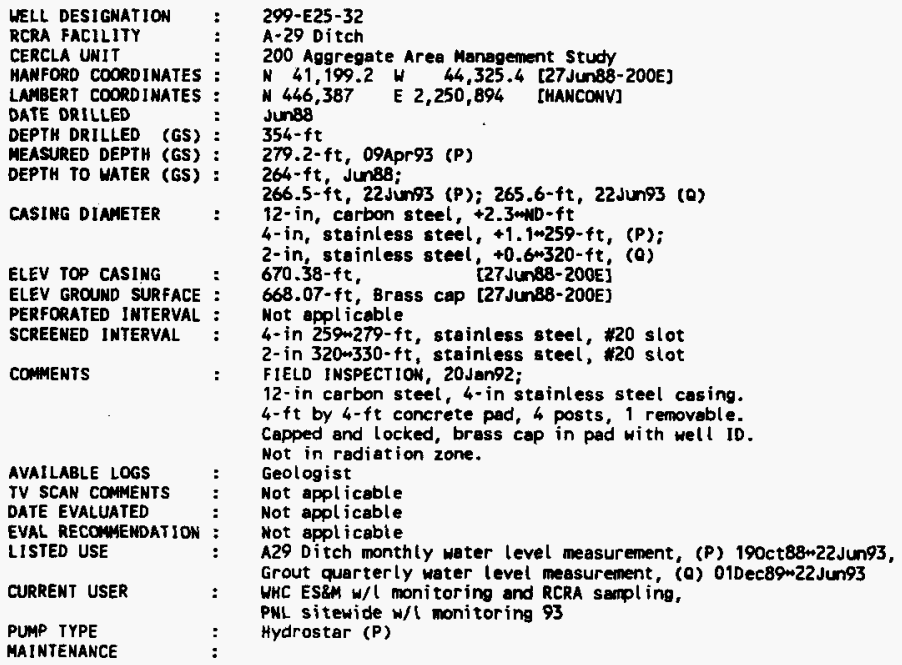




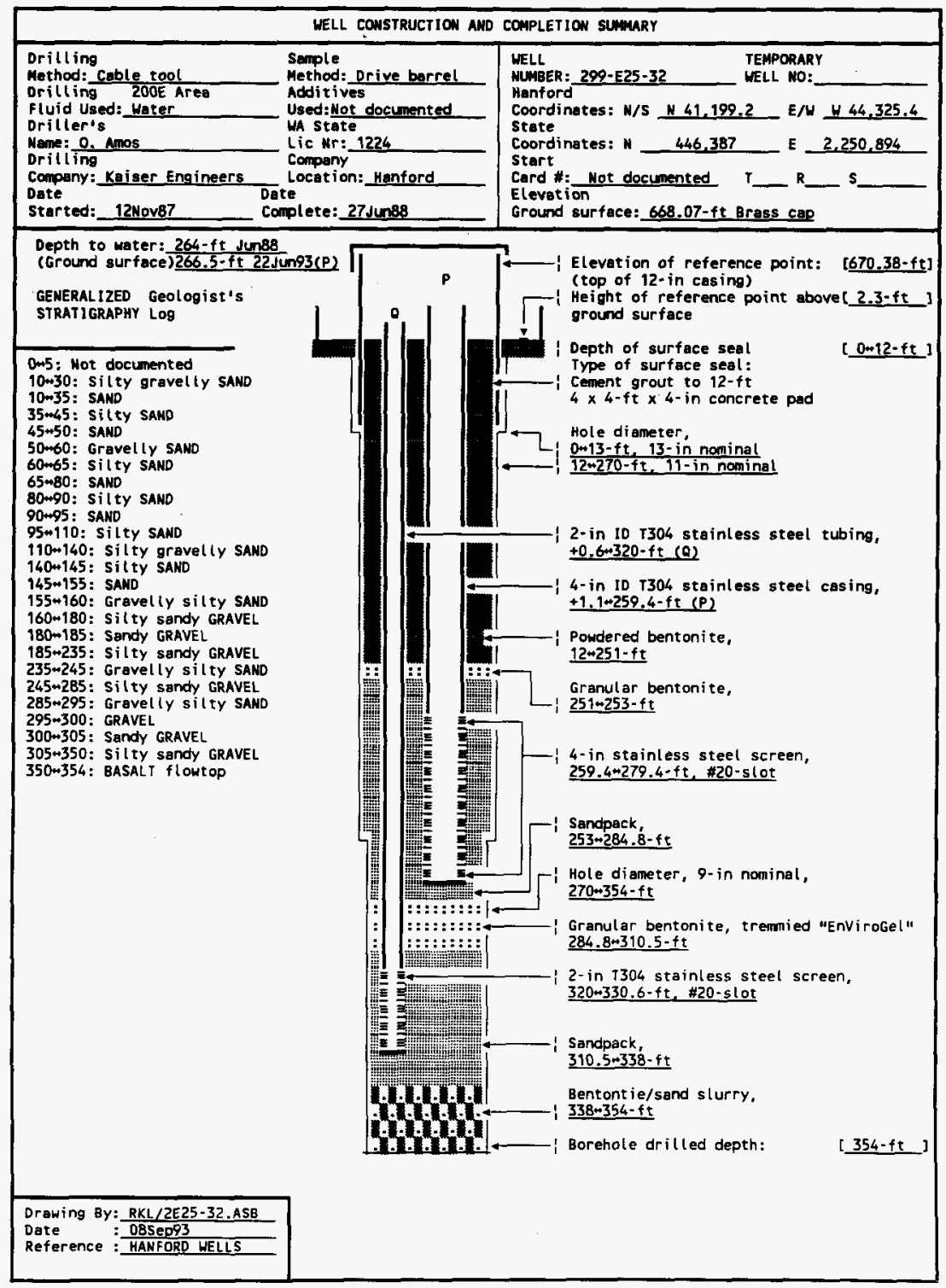




\section{SUMMARY OF CONSTRUCTION DATA AND FIELD OBSERVATIONS RESOURCE PROTECTION WELL - 299-E25-33}

MELL DESIGMATION
RCRA FACILITY
CERCLA UWIT
HAMFORD COORDINATES
LAMRERT COORDIMATES :
DATE DRILLED
DEPTH DRILLED (GS)
MEASURED DEPTH (GS)
DEPTH TO WATER (GS) :
CASIMG DIAMETER :
ELEY TOP CASING :
ELEV GROUND SURFACE :
PERFORATED INTERVAL :
SCREENED INTERVAL
COMWENTS

AVAILABLE LOGS TV SCAN COMGENTS DATE EVALUATED

EVAL RECOMMENDATION : LISTED USE CURRENT USER

PUMP TYPE MALUTENANCE

\section{R99-E25-33}

Grout

200 Aggregate Area Monagement Study

N $40,116.20 \mathrm{~W} 45,609.55$ [28Juns8]

N 445,301

E $2,249,613$ [HANCONV]

Mar88

400-ft

Yot documented

$266.5-\mathrm{ft}$, Mar88;

$247-\mathrm{ft}$, 010ec92

6-in, stainless steel, +2.62 - $0.5-\mathrm{ft}_{\text {; }}$

$4-i n$, stainless steel, +NDw261.9-ft

650.23-ft, [27mar92-NGV'29];

$674.97-\mathrm{ft}$, [27JunB8]

Not documented

Not applicable

261.9-282.2-ft, 4-in stainless steel, \#20-slot

FIELD INSPECTION, 12AL989;

stainless steel casing. 4 -ft by $4-\mathrm{ft}$ concrete pad, 4 posts, 1 removable capped and locked, brass cap in pad with well 10 .

OTHER; Casing was apparently cur off 25 -ft ofter JunB8.

Geologist

Not appliceble

Not appl icable

Not applicable

Grout semiannual water level measurement, 08Jul88m010ec91;

WHC ES\&M W/I monitoring and RCRA sampling,

PNL sitewide sampling 93

Hydrostar 


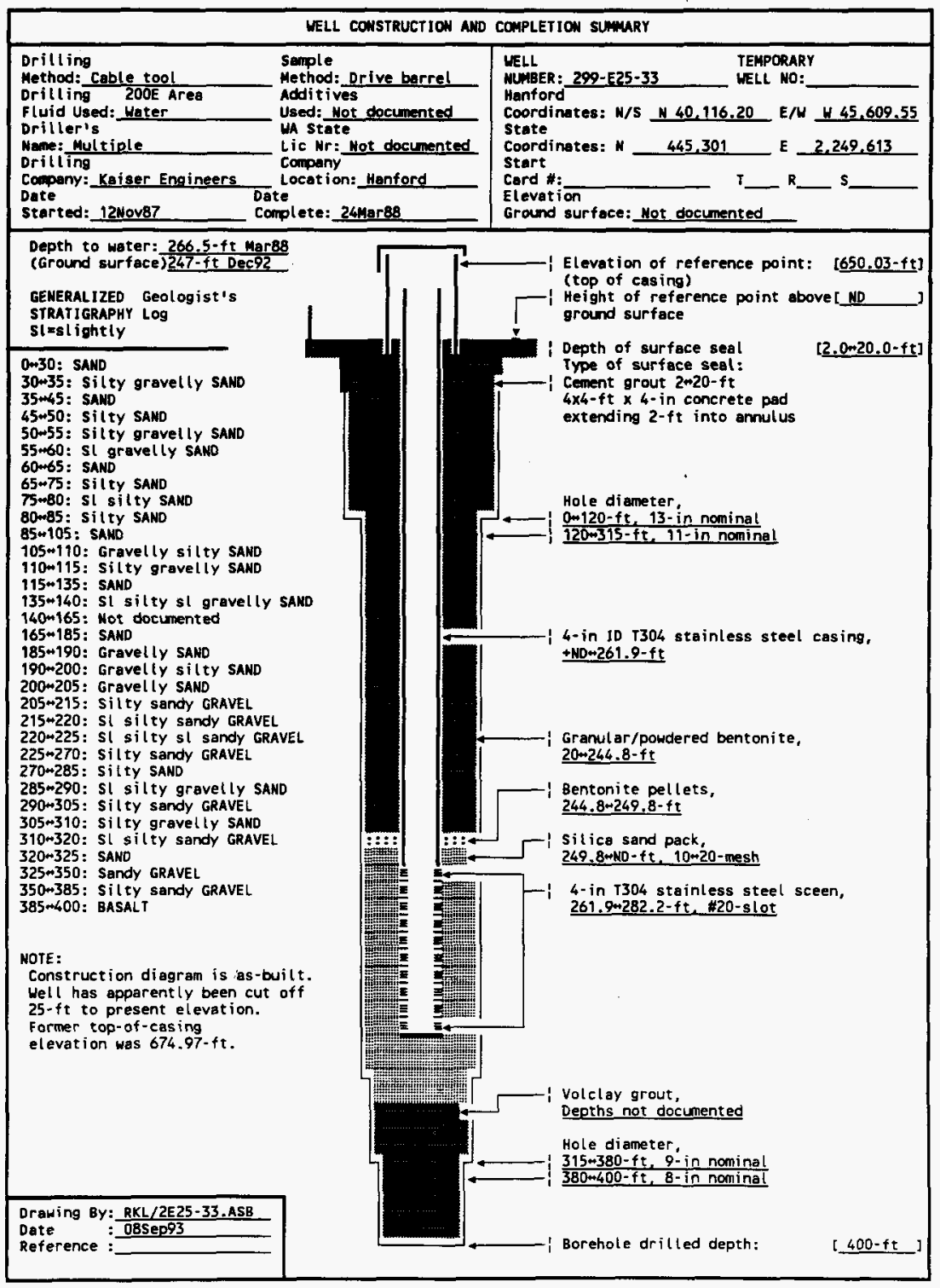




\section{SUMMARY OF CONSTRUCTION DATA AND FIELD OBSERVATIONS}

RESOURCE PROTECTION WELL - 299-E25-37

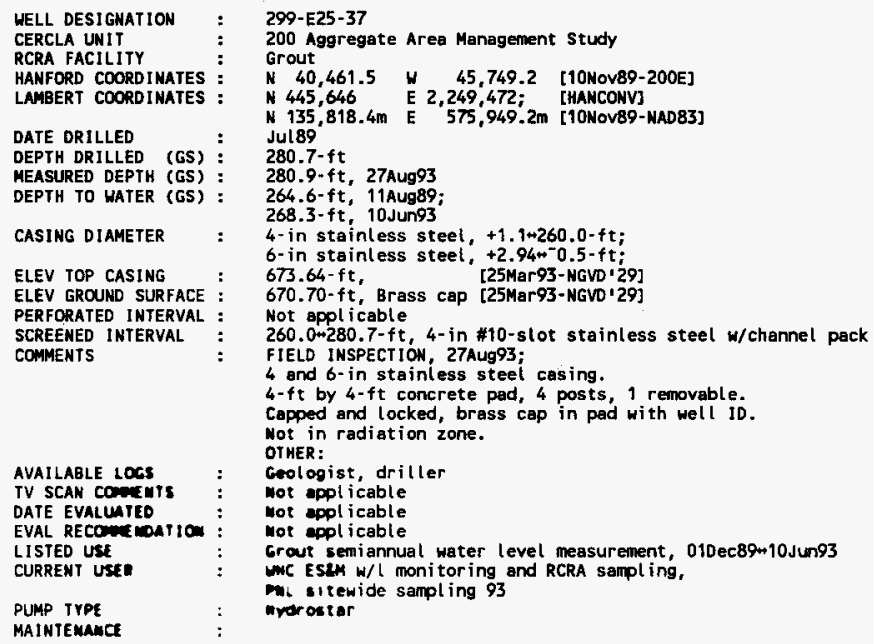




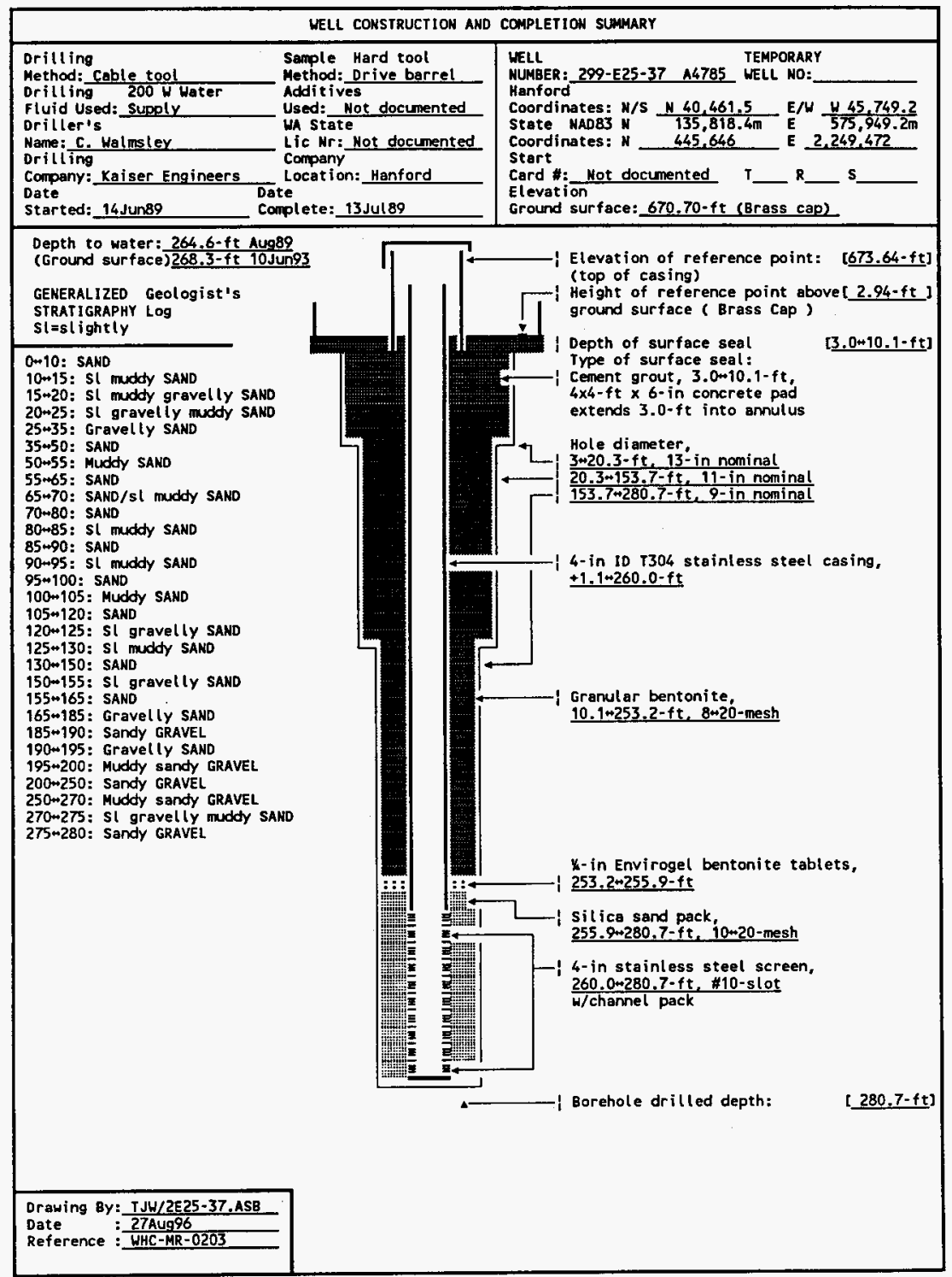




\section{SUMMARY OF CONSTRUCTION DATA AND FIELD OBSERVATIONS RESOURCE PROTECTION WELL - 299-E25-38}

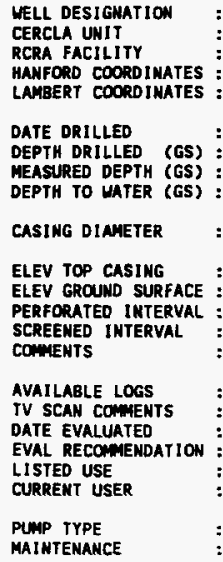

299-E25-38

200 Aggregate Area Management Study Grout

N $40,056.4$ W $45,469.0$ [10NovB9-200E]

N 445,241 E 2,249,753; [HANCONV]

N 135,695.2m E 576,034.9m [10NOVB9-NAD83]

Sep89

283.0- $\mathrm{ft}$

Not docunented

265.1-ft, 05Jul89:

268.2-ft, 10 Jung3

4 - in stainless steel, $+1.40+258.6-\mathrm{ft}$;

6 -in stainiess steel, $+3.0-0.5-f t$

$673.75-\mathrm{ft}$. [27Mar92-NGVD'29]

670.77-ft, Brass cap [27Mar92-NGVD'29]

Not applicable

258.6-279.6-ft, 4-in \#10-slot stainless steel w/channel pack FIELD INSPECTION,

OTHER:

Geologist, driller

Not appl icable

Not applicable

Not appl icable

Grout semiannual water level measurement, 010ec89w10Jun93;

WHC ESEM w/I monitoring and RCRA sampl ing,

PNL sitewide sanpling 93

Hydrostar, intake a 279.1-ft 


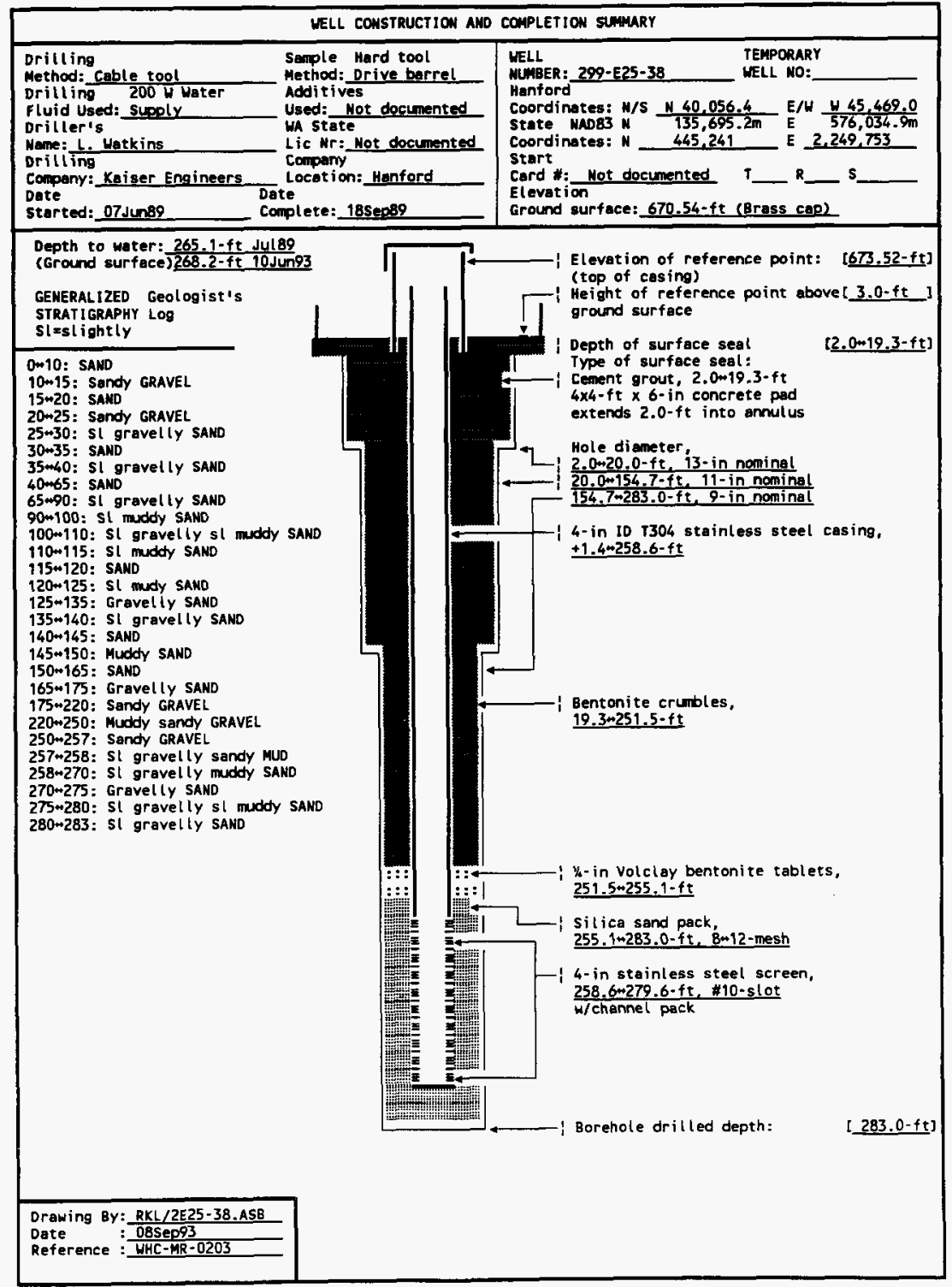




\section{SUMMARY OF CONSTRUCTION DATA AND FIELD OBSERVATIONS \\ RESOURCE PROTECTION WELL - 299-E25-39}

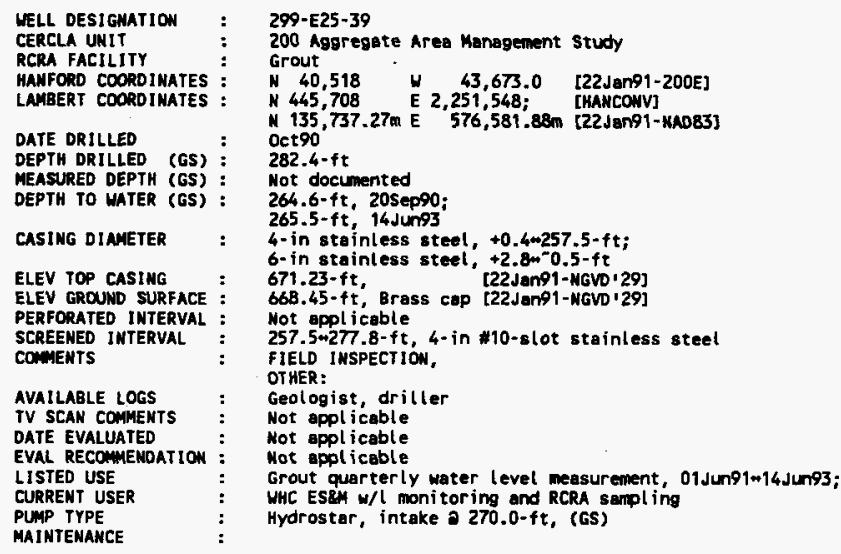




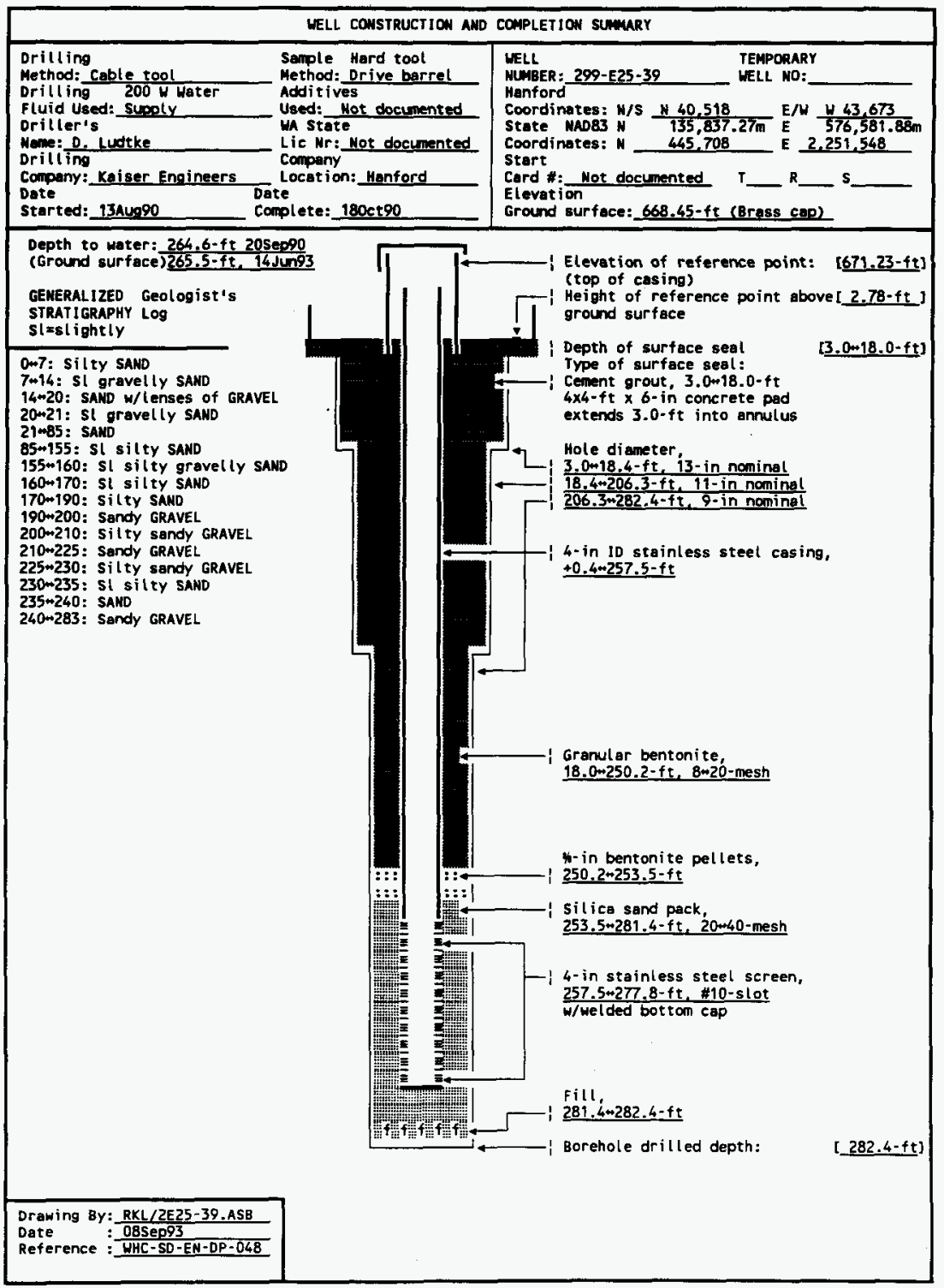




\section{SUMMARY OF CONSTRUCTION DATA AND FIELD OBSERVATIONS RESOURCE PROTECTION WELL - 299-E25-44}

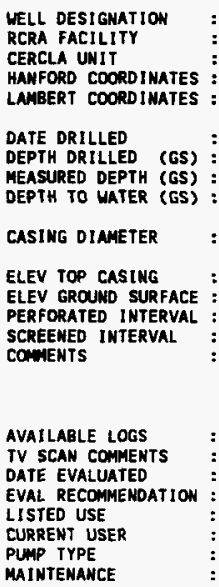

\section{9-E25-44}

Grout

200 Aggregate Area Managenent Study
M 39,930.35 W 45,222.74 [21Sep92-200E]

N 445,116 E 2,250,000 [HANCONV];

N $135.656 .934 \mathrm{~m}$ E $576,110.133 \mathrm{~m}$ [NAD83-21'sep92]

Jung2

293.3- $\mathrm{ft}$

$285.8-\mathrm{ft}, 180 \mathrm{ec} 92$

269.2-ft, 02 Juns?

270.3-ft, 180 ec92

6-in, stainless steel, $+2.4-0.5-\mathrm{ft}$;

$4-i n$, stainless steel, +NDm-265.8-ft

675.29-ft, [21Sep92-NGVD'29]

672.90-ft, Brass cap [21Sep92-NGVD 29]

Not appl icable

265.8+285.9-ft, 4-in stainless steel, $\$ 10-s$ lot

FIELO INSPECTION, 18Dec92;

Stainless steel casing. $4-\mathrm{ft}$ by $4-\mathrm{ft}$ concrete pad, 4 posts, 9 removable capped and locked, brass cap in pad with well ID.

Wot in radiation zone.

Geologist

Not appl icable

Not appl icable

Not appl icable

No. water level data;

WHC ESEM RCRA sampl ing

Hydrostar 


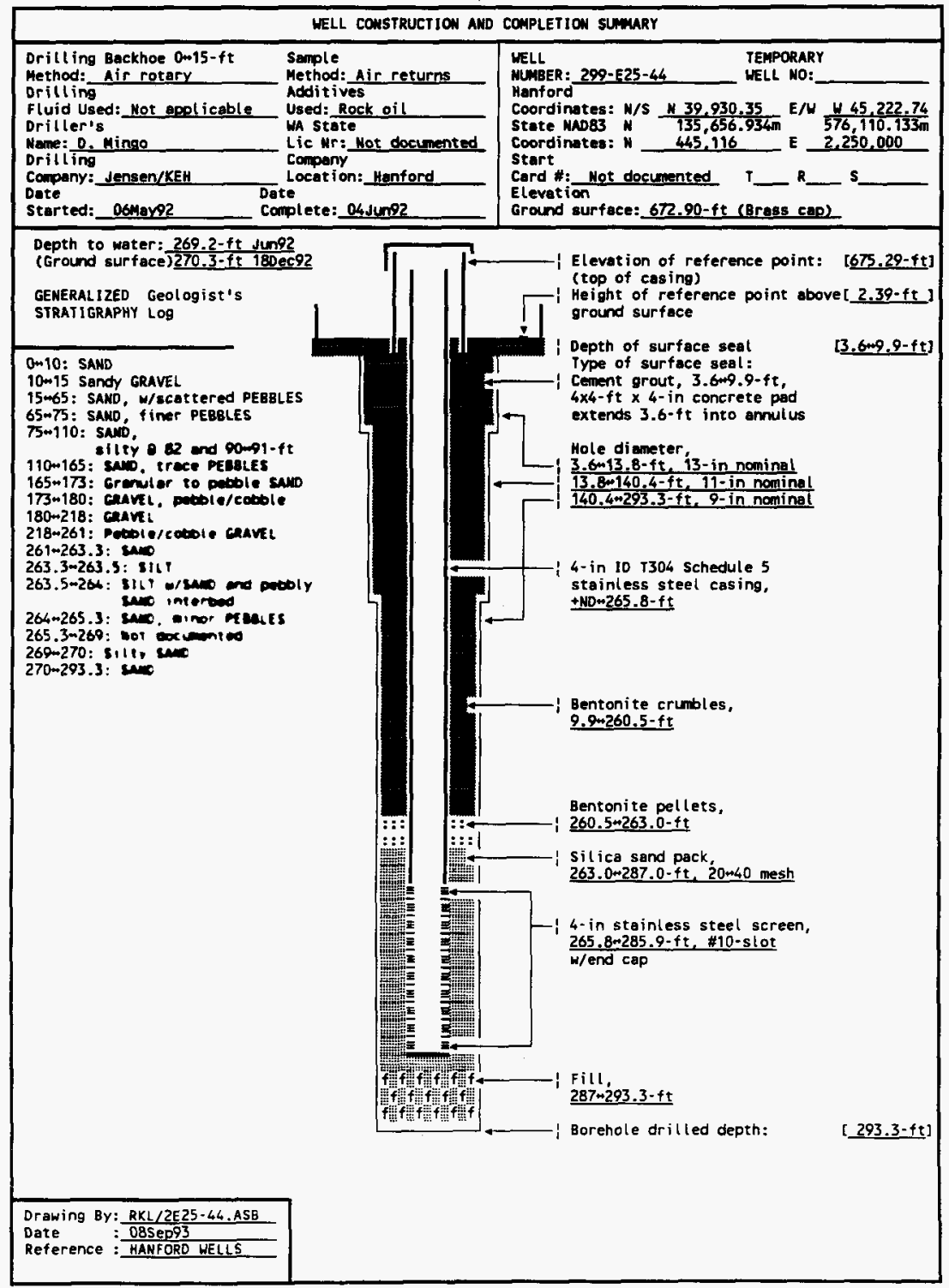




\section{SUMMARY OF CONSTRUCTION DATA AND FIELD OBSERVATIONS RESOURCE PROTECTION WELL - 299-E25-45}

WELL DESIGNATION
RCRA FACILITY
CERCLA UNIT
HANFORD COORDINATES
LAMBERT COORDINATES :
DATE DRILLED
DEPTH DRILLED (GS)
MEASURED DEPTH (GS)
DEPTH TO WATER (GS) :
CASING DIAMETER :
ELEV TOP CASING
ELEV GROUND SURFACE :
PERFORATED INTERVAL :
SCREENED INTERVAL
COMHENTS

avallable LogS

IV SCAN COMMENTS

DATE EVALUATED

EVAL RECOMMENDATION :

LISTED USE

CURRENT USER

PUMP TYPE

MAINTENAKCE
299-E25-45

Grout

200 Aggregate Ares Management Study

N 39,937.7 44,973.2 [J00ec92-200E]

N 445,126 E 2,250,249 [HANCONV]:

N $435,659.15 \mathrm{~m}$ E $576,185.55 \mathrm{~m}$ [NAD83-300ec92)

Jul 92

297.6-ft

Not documented

$271.9 \cdot \mathrm{ft}, 30 \mathrm{Jun} 92$

$280.4-\mathrm{ft}$, $180 \mathrm{ec} 92$

6-in, stainless steel, +2.7-0.5-ft;

$4-$ in, stainless steel, +NDm269.4- $\mathrm{ft}$

678.45-ft, [30Dec92-NGVD'29]

675.74-ft, Brass cap [30Dec92-HGVD'29]

Not apol icable

269.4m289.6- $\mathrm{ft}, 4-$ in stainless steel, $\# 10-8$ lot

FIELD INSPECTION, 18Dec92;

4 and 6-in stainless steel casing.

4- $\mathrm{ft}$ by 4 -ft concrete pad, 4 posts, 1 removable.

Capped and locked, brass cap in pad with well ID. Not in radiation zone.

Geologist

Not applicable

Not apolicable

Not appl icable

Ho water level data;

WHC ESEM RCRA sampling,

Hydrostar 


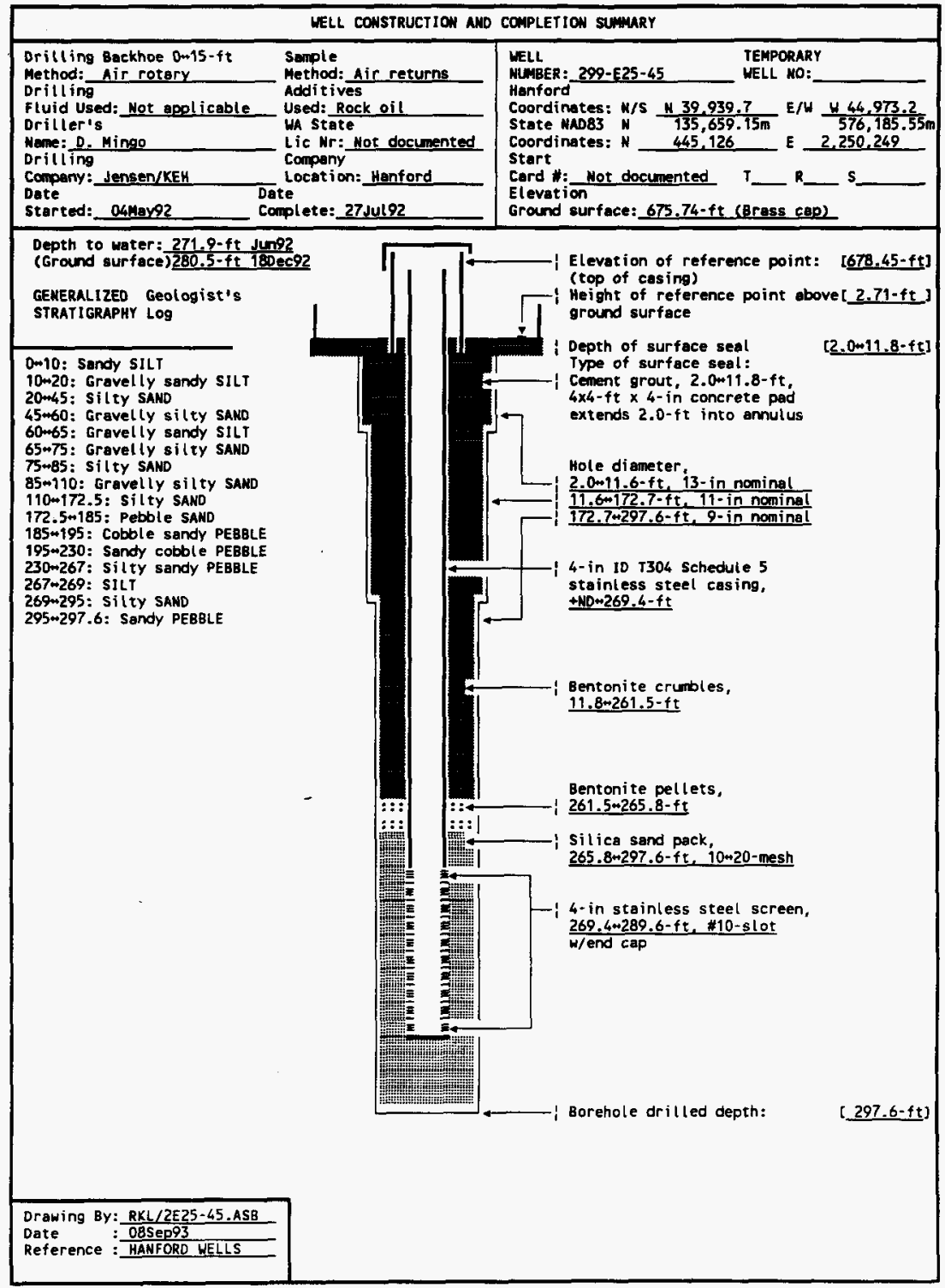




\section{WHC-SD-WM-ES-398 Rev. 0 VALIICATED}

WELL CONSTRUCTION SUMMARY REPORATGNATURE/DATE

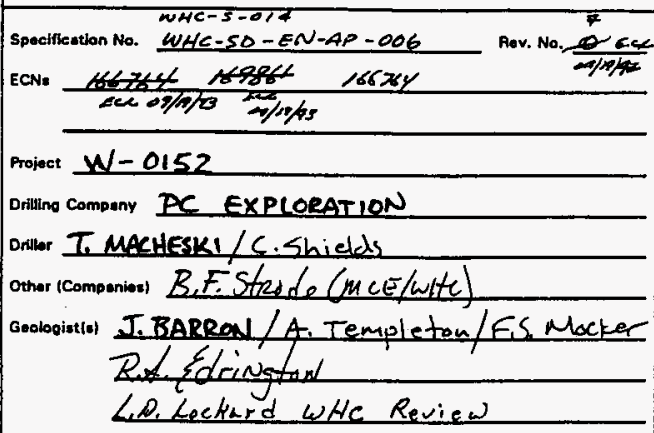

\begin{tabular}{|c|c|c|}
\hline \multicolumn{2}{|c|}{ Woil No. $z 49-E 25-49$} & Tomp. Well No. $299-278549$ \\
\hline Approximate Location & GRour & MENT FACILITY (GTE) \\
\hline
\end{tabular}

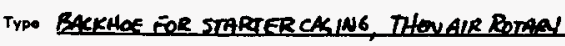

Drillino Fluid $N / A$

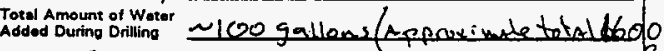

(1) $C$ is commente Columbias Raw River water was

used during drilling activities from $\sim 282^{\circ}$ to $293^{\circ}$ dae to heaving sand in that intervale LP. Leekard whe Review

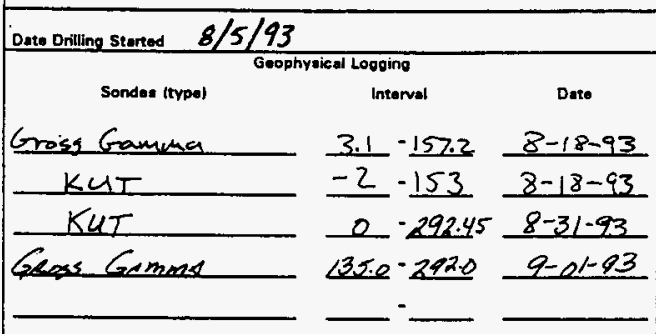

\begin{tabular}{|c|c|c|}
\hline \multicolumn{3}{|c|}{ Temporary Ceaings and Drilled Depth } \\
\hline Cesing Type end Size & Interval & Shoe OD \\
\hline$C S-12^{\prime \prime}$ DaAn. & $0.12,1^{\prime}$ & $N / A$ \\
\hline$C S-10^{\circ}$ DIAM & $-158^{\prime}$ & $N / A$ \\
\hline$C S-8^{\circ}$ DIAM. & $0 \begin{array}{l}-48-21793 \\
+5=5\end{array}$ & $N / A$ \\
\hline Drillod Depth $293^{\prime}$ & Hole Diamator at & $n$ \\
\hline
\end{tabular}

Compietion Activity

Type

Caxing and Screen (Pomenent)

$4^{\prime \prime} 55-304 \quad 289.50-289.18 \quad 0.32^{\prime} \quad$ ENOCAP

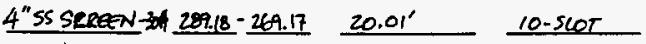

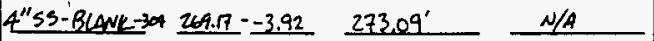

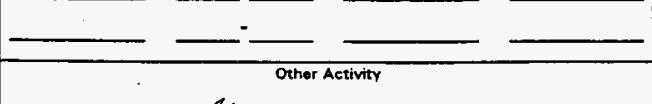

Aquiter Tort Perfomed? Wey

Typo Instanterverus Slug Date $9 / 24 / 93$

Woll Abandoned?

Dete

\begin{tabular}{|c|c|c|c|}
\hline \multicolumn{4}{|c|}{ Annular Seal/fittor Pack } \\
\hline Typo & Interval & volume & Mosh Sizo \\
\hline Suca SAND & $\begin{array}{l}292.3 \\
29302 \\
264.0\end{array}$ & 10.09 cuft & $20-40$ \\
\hline Bovtonite Paners & $2640-2544$ & $1.24 \mathrm{custt}$ & $1 / 2 *$ \\
\hline Granular Bomentr & $25,4-120$ & $198.09 \mathrm{cu} \mathrm{ft}$ & $8-20$ \\
\hline Wid Comears & $12.0-2.0$ & 20,56 & TWDEITII \\
\hline \multicolumn{4}{|c|}{ Well Survoy Data } \\
\hline $11 / 16 / 8$ & & & \\
\hline \multicolumn{4}{|c|}{$\begin{array}{l}\text { Wathington State } N 135668,325, E 576291.697 \\
\text { PTime Coordinates }\end{array}$} \\
\hline \multicolumn{4}{|c|}{ Protoetive Casing Elovation 678.660} \\
\hline Bras: Cap Elevation & $675: 44$ & & \\
\hline
\end{tabular}

\begin{tabular}{|c|c|c|}
\hline Static Water Level/Date & $273.19^{\prime} e 0718$ & $8-25-93$ \\
\hline Comment: & $272.3^{\prime} \odot 14.59$ & $9 / 10 / 93$ \\
\hline
\end{tabular}


WHC-SD-WM-ES-398 Rev. 0

WELL SUMMARY SHEET
19293

Boring or Wall No. $299-E 25-49$

sheot 1 of 2

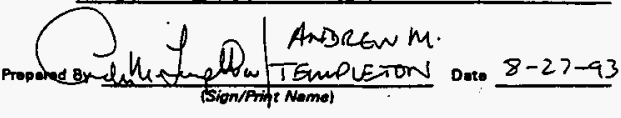

Locution $21500^{\prime}$ EAST of GTF

Proiset $h-152$

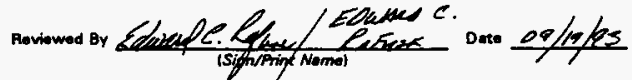

\begin{tabular}{|c|c|}
\hline \multicolumn{2}{|c|}{ GEOLOGIC/HYDROLOGIC DATA } \\
\hline Graphis Log & Lthologic Description \\
\hline
\end{tabular}

TEMP. 12" CS casent SET e 12.1' TIIN LAWER of GanvUAR sEnTONINE zen $50^{\circ}$ BACS AROUND CASING BASE Pogzand Canor - It $2.0^{\prime}=12.0^{\circ}$

\begin{tabular}{l} 
Temp. $10^{\prime \prime} \mathrm{Cs} \operatorname{cosing}$ \\
Set at $158^{\prime}$ \\
\hline
\end{tabular}

Temp. $8^{\circ} \mathrm{CS}$ casing

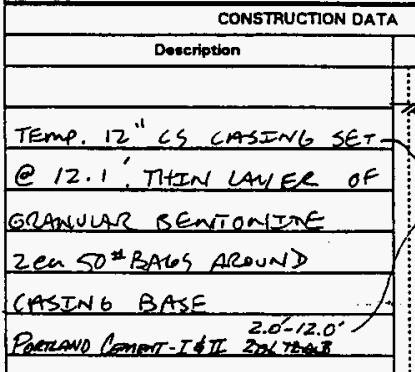

Diseram

Dopth
in
Foet

\begin{tabular}{|c|c|c|}
\hline Grsphis Log & Lthologic Description \\
\hline
\end{tabular}

\begin{tabular}{|l}
\hline \\
\hline \\
\hline Temp. $10^{\prime \prime} \mathrm{cs}$ \\
\hline Setat $158^{\prime}$ \\
\hline
\end{tabular}

(20)

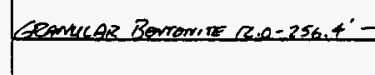


WHC-SD-WM-ES-398 Rev. 0

WELL SUMMARY SHEET

173 of 3

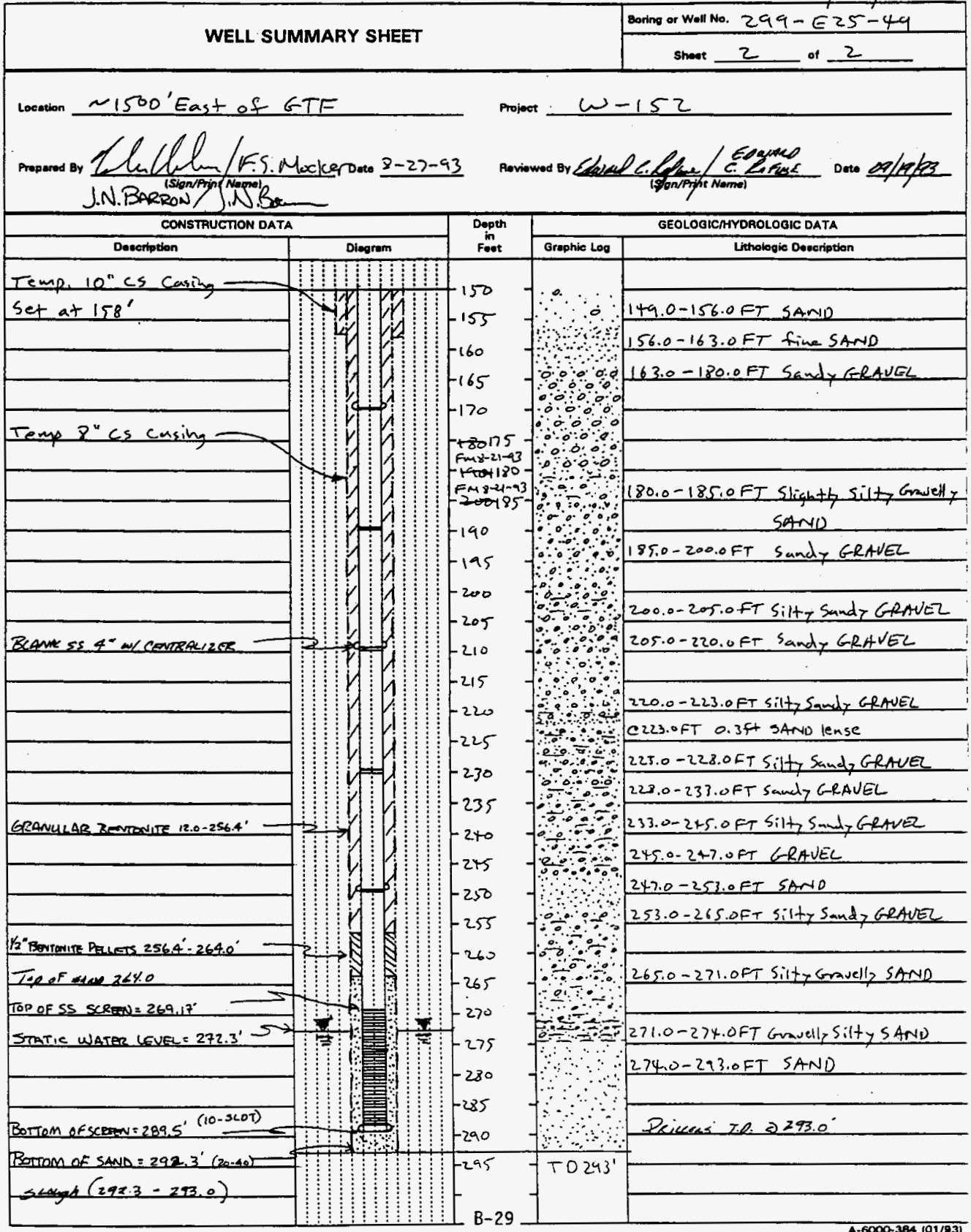


I WHC-SD-WM-ES-398 Rev. J/ALIDATED $\quad \rho_{q} / q^{3}$

WELL CONSTRUCTION SUMMARY REPORT SIGNATUREJDATE

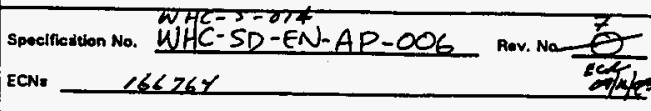

Project $w-0152$

Driline compariy PC EXPLORATION

oriter Tim MACheskl

Othor (Companies)

Gooloointiol J. Earenon, F.S. Mucker

Dufdrinstow (w the)

L. D.Leckard WHC Peview

\section{Date Drilline sterted $8 / 6 / 93$ \\ Gophryaical Logeing}

Sondes (trpe)

Interval

Date

kUT

xys

Geset Gunax
Woll No. $289-275-50$

Approximate Locotion GRoeT TRoATmenT EACLCTI

Drill Mothod

Type Backbee for starter casing, then Alr Rotary Drilling Fluid $N / A$

Total Amount of Wator
Added During Drilling

Comments

Tamporary Casinge and Drilled Depth

Cating Trpe and Size

Interva!

Shoo 00

CS - 12" DIAM.

CS $-10^{\prime \prime} 0.1 \mathrm{Atm}$

CS- 8" DiAm

Dritled Dopth 294.2

$\frac{0}{0}-\frac{15.1}{82^{\prime}}$

$0-293^{\prime}$

$N / A$

$N / A$

Hole Dismotor at TD Pinch

Ftatic Water Levol/Dato $272.12^{\prime}$ e 1540 on $a-10-93$

commont: So, subsidence occured around atsids

-f temporary casing after downsizing to $8^{\prime \prime}$ casing $82^{\prime}$

Completion Activicy Dato Sterted $9 / 14 / 93$

Cesino and Screen (Pormenent)

Type

Depthe

Length

Slot Size

$304 / 5 s$ $289.70-209.38$

$0.32^{\prime}$ ENO CAP

$304 / 55$ $304 / 55$

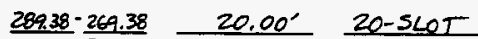
$269.38-293-3.69$
The

Typo Ann

SuLCA 54ND $294.1=264.8$ Somave 42Lers $264.8-261.0$ 9.10 cu. 0.93 Cu. Geamuar nowir $261.0=10.7$ 90.17 . Perlawo cemarr $10.7=1.0$ 21.84 CM.ET

TYPET \&II
Aquifer Tert Portormed? No Slug test parfoemen Typo $N / \mathbb{A}$ Date 912793

Well Abendoned?

Date

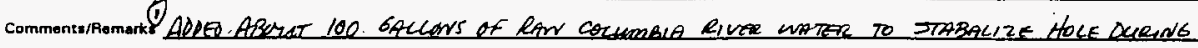
BackpuLtal6

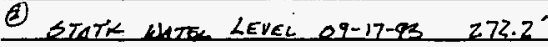

\section{Well Survey Dats}

$11 / 16 / 93$

Washington State $\mathrm{N}: 135681.613 \mathrm{E}: 576399.049$

Protoctive Cosing Elovation $677.60^{\circ}$

Brose Cap Elovation 675.32 
'WHC-SD-WM-ES-398 Rev. 0

$\operatorname{Pg} 2 P_{3}$

WELL SUMMARY SHEET

Boring or Wou No. $299-E 25-50$

shoot 1 ot 2

Location EROUT TReamient FPCIGITY

Proper $w-0152$

Propand By J.R.BuzeoN ISpon/Arine Namel

Dare $8 / 6 / 93$

CONSTRUCTON DATA

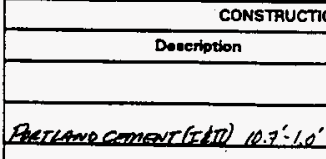

E"remp CS
$1 z^{\prime \prime}$ reme cs sere $15.1^{\prime}$

(1:!:

Oingrem

:

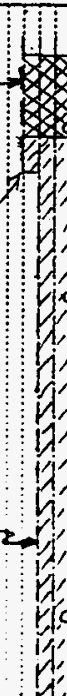

$10 "$ TEmPCS SETE $=2$

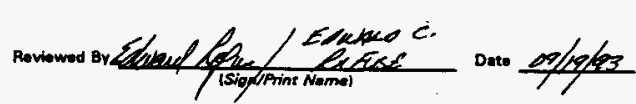

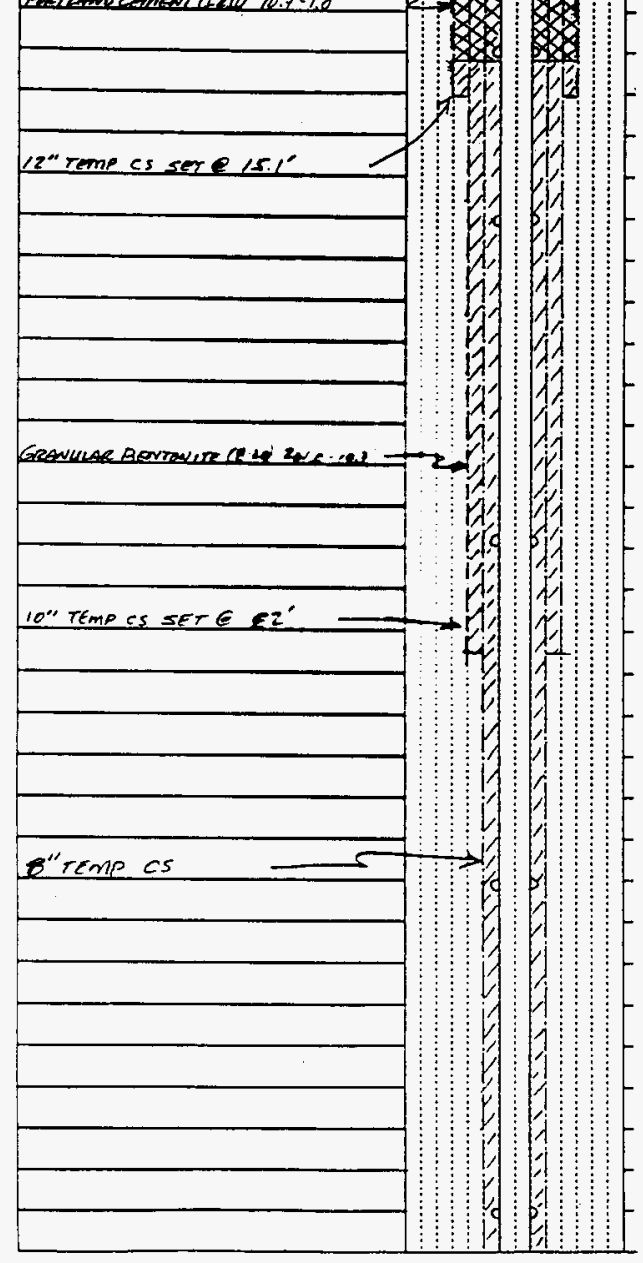

Depth

Feet

\begin{tabular}{|c|c|}
\hline \multicolumn{2}{|r|}{ GEOLOGICIHYDAOLOGIC DATA } \\
\hline Graphic Log & Lthologic Dexcription \\
\hline & 0.5 SANOY $51 \angle 7$ \\
\hline$\because$ & 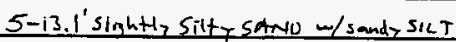 \\
\hline & Lenges \\
\hline & $13.1^{\prime}-38^{\prime}$ SANO \\
\hline$\therefore$ & $v$ \\
\hline & $\mu$ \\
\hline
\end{tabular}


I WHC-SD-WM-ES-398 Rev. 0

WELL SUMMARY SHEET

Boring or Woll No. $299-E 25-50$

shere 2 of 2 ?

Locution EROuT TREATM ENOT FAC/LITP

Project W-0152

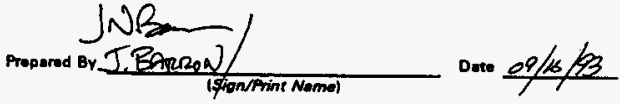

Roviownd 8y
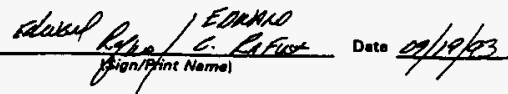

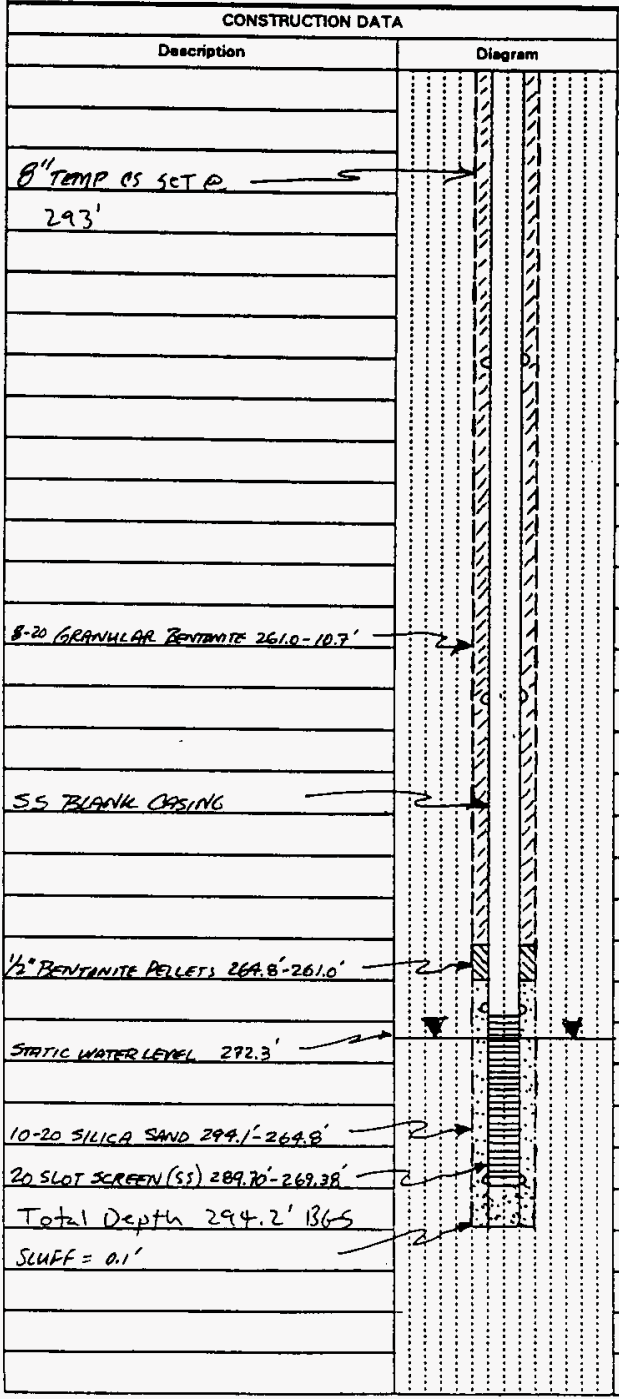

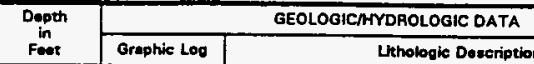

160 Silt 74 SAND

$165-100 \div 158^{\prime}-164^{\prime}$ SAND

$170-\because \because \div \because \because 16 \psi^{\prime}-200^{\circ}$ Gruell, Silt, SANO

175

180

165

190

195

200

2005

210

2,5

220

220

225

230

235

240

245

250

255

260

265

270

275

280

章政

Finc

-290

245

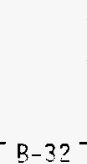

$200^{\circ}-227^{\circ}$ silt, Sand, Gravel

$\overline{0} \overline{0}: 0$

$\because \because 0=0$

$\because \frac{0}{2}, \cdots$

숭ㅇㅇㅇ:

$\because 00$

$\therefore 227^{\prime}-228^{\prime}$ SANU

$\because \because 228^{\prime}-229^{\prime}$ GRAVEL

$\because 20: 229^{\prime}-230^{\circ}$ SANO

* $0^{\circ} \circ 229^{\circ}-230^{\circ}$ sanu

$\because \div \div 0230^{\circ}-245^{\prime}$ silt, sand, GeAvEc

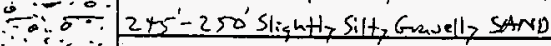

$\therefore 0, \because \therefore$

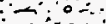

$\therefore \because \because \because 250^{\circ}-255^{\prime}$ sorid

$\because 0255^{\prime}-26051$ ightl, Silt, Gruvell, SANO

$\because 0 \therefore-26$

$\therefore \because \therefore 260-268.8$ Gouell 5 SAND

$000000268.8-269.85$ Grarel

$\because \because \because 220-274 \mathrm{Sl}_{i 3 h+1} \mathrm{Sil}_{i}$, Grusell, SANO

$\div-\div=$

$\because \because 0: \because$ cos 24 T+p of Ring d F FM

$\because-224^{\prime}-29 x^{\prime}$ Gravell $>$ Silt> 5 ANO 


\section{WHC-SD-WM-ES-398. Rev. O VALIDATED $P /$ \% \\ WELL CONSTRUCTION SUMMARY REPORT SIGNATURE/DATE \\ Pago 1 i of 1}

Spoelfieation No. $204 C-5-0 / 4$

$\mathrm{ECN}$

Project $W 0152$

Driline Compeny PC Explordtion

Drilur T macheski. C. Shields

ormar (Compenwa) Golder Associates

Geologintes $T$. Barron

A. Templeton

F. Mocker

Lr. Anderson R.S. Eolrington

L.D. Lockard wAle Revied

Date Drilling Stemed $8 / 9 / 93$

Sondes (type)

Interval

Dato

SUT

$0.175 \quad 9-16-93$

ruT

Neutron Gapture

Woll No. 299-EZ5-1000 Tomp. Wall No.

Approximato Location Grout Treeteneat Facelety

Deill Method

Typo Backoe Excew for starter caseng / arr cotacy Drilling Fluid

Total Amount of Water

Asded During Drilling

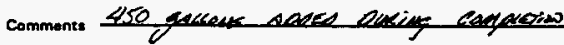

pexers.

Temporary Catinge and Drilled Depth

Casing Type and Sizo

Interval Shoe oD

$\frac{\operatorname{cs}-12^{\prime \prime}}{\cos -10^{\prime \prime}}$

cs-10"

cs - 8"

Drilled Depth $391.89^{\prime}$

Static Water Level/Dato $267.44 \quad 10 / 22 / 93$

Commonte

Complesion Activity

Cesing and Screen (Permenent)

Typo
casiry

Tepe 304

Terae 304

Cont wrap

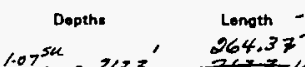

Longth -

$\frac{1.070}{0}-263.3$ $203.3^{\prime}-293.6$

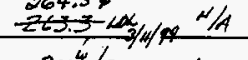

Siot Sizo

$N / 4$

Type

Entonite

hole plus

$10-20$ sand

$20-40$ sand

3/*ellets

kble olug.

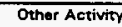

N/A

Aquiter Test Pertormed?

Orner Activity

Ty

Well Abandoned?

$N / A$

$N / A$

Dote $N / A$

Dosto

$\overline{N / A}$

Commentu/Romarki Sec $N C R^{*} 050058$, EQA-93-100;

$N C R^{\circ} 050961, E R A-23-105$
Hoio Dlamoter at TO

Date Started $10 / 25 / 93$

\section{Oato Started}

Interval Volume $297.5^{\prime}-3916^{\prime} 62.1$ cuft.

Mash Sizo $297.5-3916,62.1$ cutf. $>1 / 2$ 293.4-297.5' $214 \mathrm{cutt}$ $10-20$ $258.5-2954^{\prime}$ 12.3 Catt $2543^{\prime}-258.5^{\prime} \quad 1.55 \mathrm{cuft}$. $243.1^{\prime}-254.3$ 2.76 cuft.

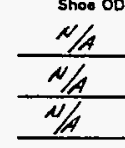

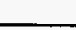




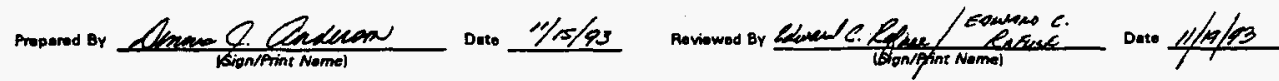

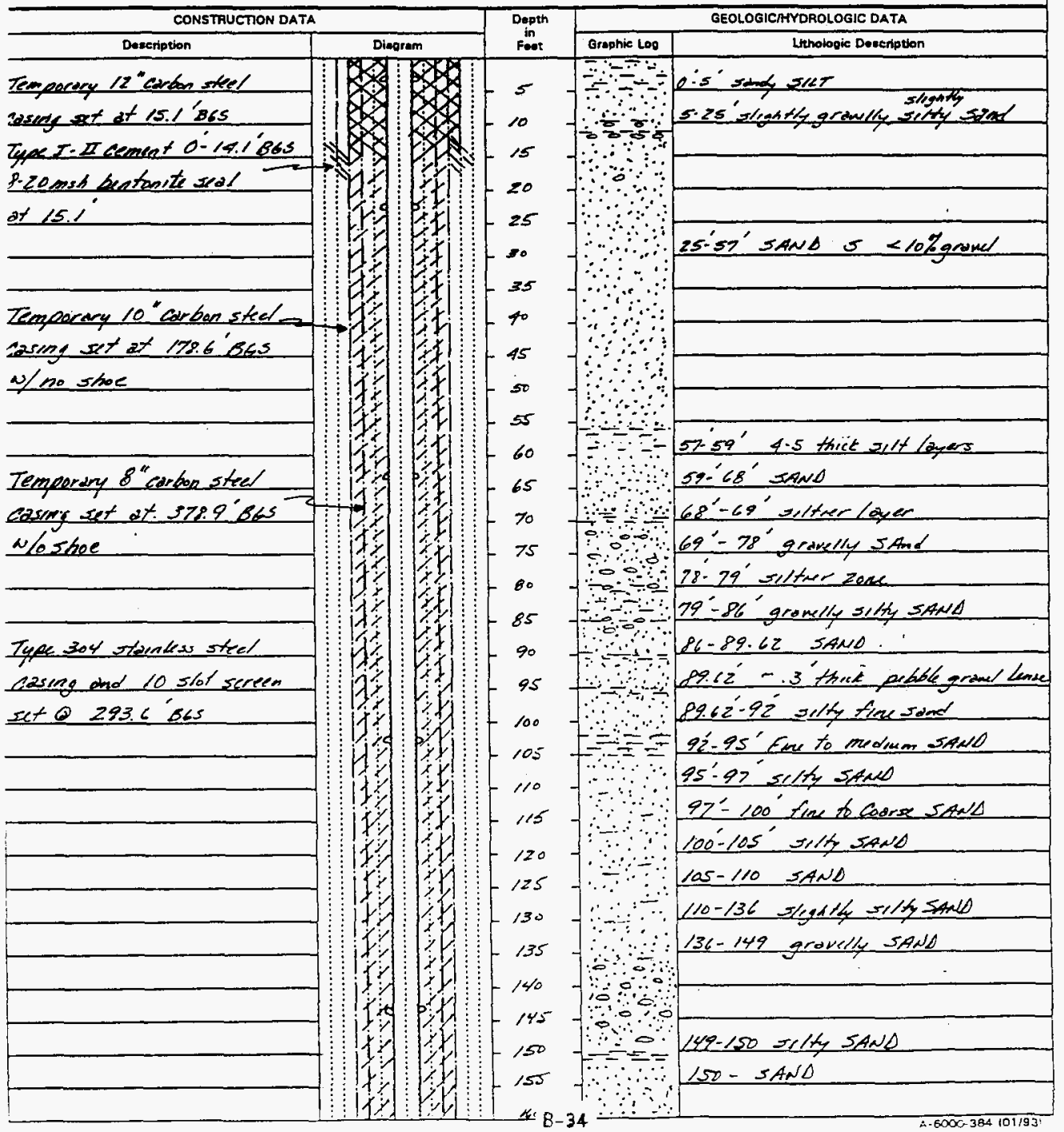




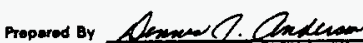
Bipn/tint Nemel

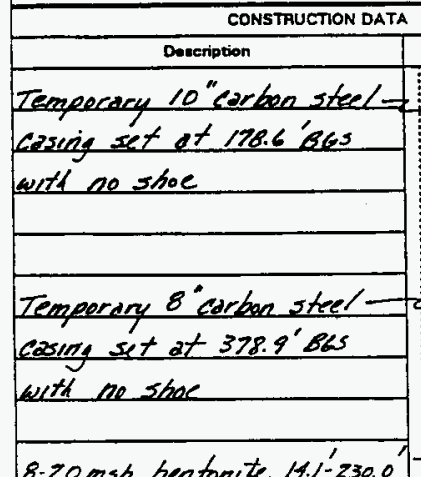

8-20msh bentomite 11.1-230.0 10-20 send 230.0'-25z.4' Eecmetion $232.4^{\prime}-232.9^{\prime}$ 10-20 5mod 232.9'-257.8' Formation 237.8'-245.' Note: see NCR 05096! dtfocked thole plug $>1 / 2$ "243.1'-254.3 Non-budeded $3 / 8$ "bentonite pellets 254.5'-258.5's6s

20-40 5AND $258.5^{\prime}-293.4$

Type 304 continuous stainless steel sereen - $10510 t$ $263.3^{\prime}-293.3^{\prime} B 65$ stankss steel end cap 299.3'- 293.6 ' $30 \mathrm{~s}$ $10-20$ 5and $293.4^{\prime}-297.5065$ Hele plue $->1 / 2$ "in size $297.5^{\prime}-391.6800$ Note: sand interral $35 \% 0.55 \% 8$

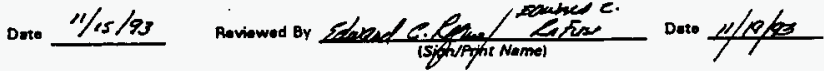

Dienram

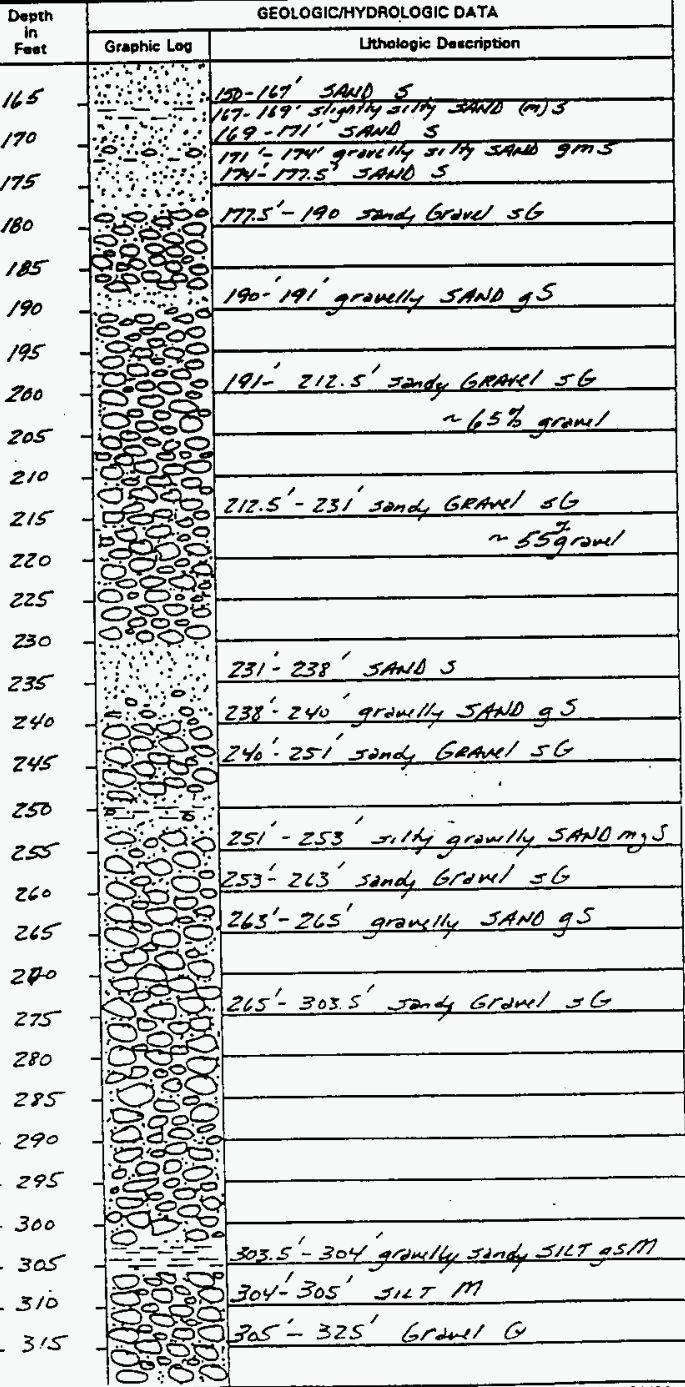


Locotion GTF: Edst of $200 E$ Ared

Projetet $w-0152$

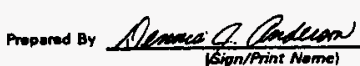
CONSTRUCTION DATA Deseription

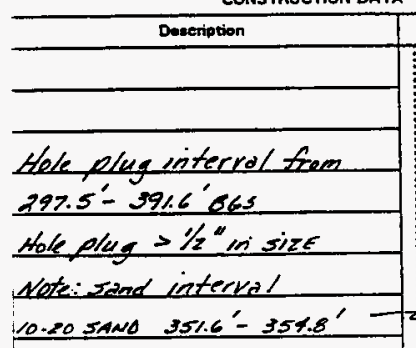

Temporary 8 "carken steel. casing set of 378.9'scs with shoe

slouges $=391.9-591.6^{\circ}$ B65

Wete: NeC 05005B 1sseed $10 \% / 93$ for forlure to characterize the interval 260 ' 325 ' $\mathrm{s} 65$ wer cloxed on 10/20/93 see attoched copy

Note: NCR os 0961 levered for sloughing $/$ formation against 4 " stembers steel casing of Lentervals $232.4 \div 232.9^{\prime}$ and 237.8 - 243.1'B65
Doto $11 / 15 / 93$

$\begin{gathered}\text { Dopeh } \\ \text { in } \\ \text { Foot }\end{gathered}$
325
330
335
310
315
350
355
360
365

370

375

380

365

390

395

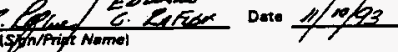

GEOLOGICMYYDAOLOGIC DATA

\begin{tabular}{|l|l}
\hline Graphic Log & Lthologic Description \\
\hline
\end{tabular}

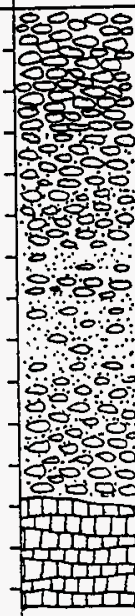

$305-325$ 'Granel $C$

$325^{\prime}-348^{\prime}$ zende Gravel $5 G$

$348^{\prime}-35 z^{\prime}$ grdwally stwd g 5

$35 z^{\prime}-355^{\prime}$ sand Gravel $5 G$

$505^{\prime}-365^{\prime}$ grovelly sawe g 5

$565^{\prime}-378.5^{\prime}$ Indy Gravel $S G$

Top of baxolt at 378.5'8es

$378.5^{\prime}-391.9^{\prime}$ b2501t (TD)

Totel depth of barehole = 391.9 865

Note: This well summory is

token from GAI's well summary: lorigunals are in log book 
WHC-SD-WM-ES-398 Rev. 0

\section{APPENDIX C}

\section{EFFICIENCY-BASED GROUNDWATER}

MONITORING NETWORK DESIGN

FOR THE PROPOSED ILLW STORAGE FACILITY 
WHC-SD-WM-ES-398 Rev. 0

This page intentionally left blank.

C-2 
The analytical Monitoring Efficiency Model (MEMO) was originally utilized to support the design of the monitoring well network at the former GTF (DOE 1990). The use of this model was instrumental in demonstrating RCRA groundwater compliance. The MEMO was rerun to determine if, after the implementation of TWRS Privatization Phase I, the remaining active (Category 3) wells near the facility will provide a similar or adequate level of groundwater monitoring coverage for the proposed ILLW storage facility. This is done to predict whether or not additional wells need to be considered for the active category. The model was rerun utilizing the same input parameters as the former GTF and the results are displayed on the diagram on page $C-5$.

The results indicate that, based on the given well locations and number, the ILLW will have a $100 \%$ coverage for leak detection. This is considered adequate to meet the most stringent RCRA regulations. Based on these results no additional wells are required.

The following paragraphs summarize how the MEMO model works and provide some background information on its development. This information is taken from Mercer (1991).

The method simulates the migration of hypothetical contaminant plumes from the site and quantifies the efficiency of alternative well network designs in detecting those plumes. The approach is relatively simple, and the computed efficiency provides a quantified basis for optimizing the design. A map of the site showing areas where releases would or would not be detected by the given well network is attached. MEMO is applied using a menu-driven computer program.

Groundwater monitoring programs are required by the EPA to verify the continuing isolation of contaminants at most hazardous waste sites (EPA 1989, 40 CFR 264.9l(a)). Although the intent of such monitoring is to protect human health and the environment through early detection of a contaminant release, a simple means for measuring the degree of protection offered by a monitoring system has not been well established. The MEMO model provides a simple method for quantifying and graphically displaying the efficiency of a given monitoring well network for detecting a potential contaminant release. The method is an extension and refinement of a physical design approach suggested by Massmann, Freeze, and others (Massmann and Freeze 1987 and Freeze et al., 1990, and Meyer and Brill 1988). It provides an easily understood way to adjust and optimize the network design to site and waste conditions, and to quantify the degree of protection for public and regulatory review. MEMO was developed at the request of Westinghouse Hanford Company, Richland, Washington, for the U.S. Department of Energy and has been used extensively in the design of groundwater monitoring networks.

To comply with current groundwater monitoring requirements, monitoring wells at hazardous waste sites must be located at intervals along the hydraulically downgradient limit of the waste disposal site (EPA 1989, 40 CFR 264.95(a)). MEMO predicts whether a contaminant release to groundwater from a specific location at the disposal site would be detected by a monitoring we 7 . This is accomplished by mathematically generating a contaminant plume and determining whether that plume is intersected by a monitoring well before it migrates beyond a specified distance from the site. The process is repeated at many locations onsite to develop a map of predicted 
locations where releases would or would not be detected. The 'monitoring efficiency' of a well network is then computed as the ratio of the area of detection to the total area of the site. For example, a determined efficiency of $90 \%$ predicts that releases occurring over $90 \%$ of the site would be detected by the monitoring wells, and releases occurring over $10 \%$ of the site would not be detected.

The model inputs consist of the transport parameters used to compute the shapes and sizes of the plumes, the directions and seepage velocity of groundwater movement, the analytical detection limits for water samples from the monitoring wells, and the extent to which the tip of a plume will be allowed to migrate beyond the disposal site boundary before it is detected. The principal outputs are the monitoring efficiency and a site map showing predicted non-detection locations.

The approach is fundamentally simple, and can be applied at most sites with available site-specific and literature-based information. Because the method is based upon a simulation of actual physical processes, evaluations of the adequacy of the design are focused upon the physical parameters and processes governing contaminant migration, rather than upon qualitative judgements of how many wells are enough. A level of uncertainty will always be present in the functioning of any groundwater monitoring network design, due to limitations on the number and spacing of wells. MEMO provides a simple way to quantify at least some of the uncertainty associated with network design. 
WHC-SD-WM-ES-398 Rev. 0

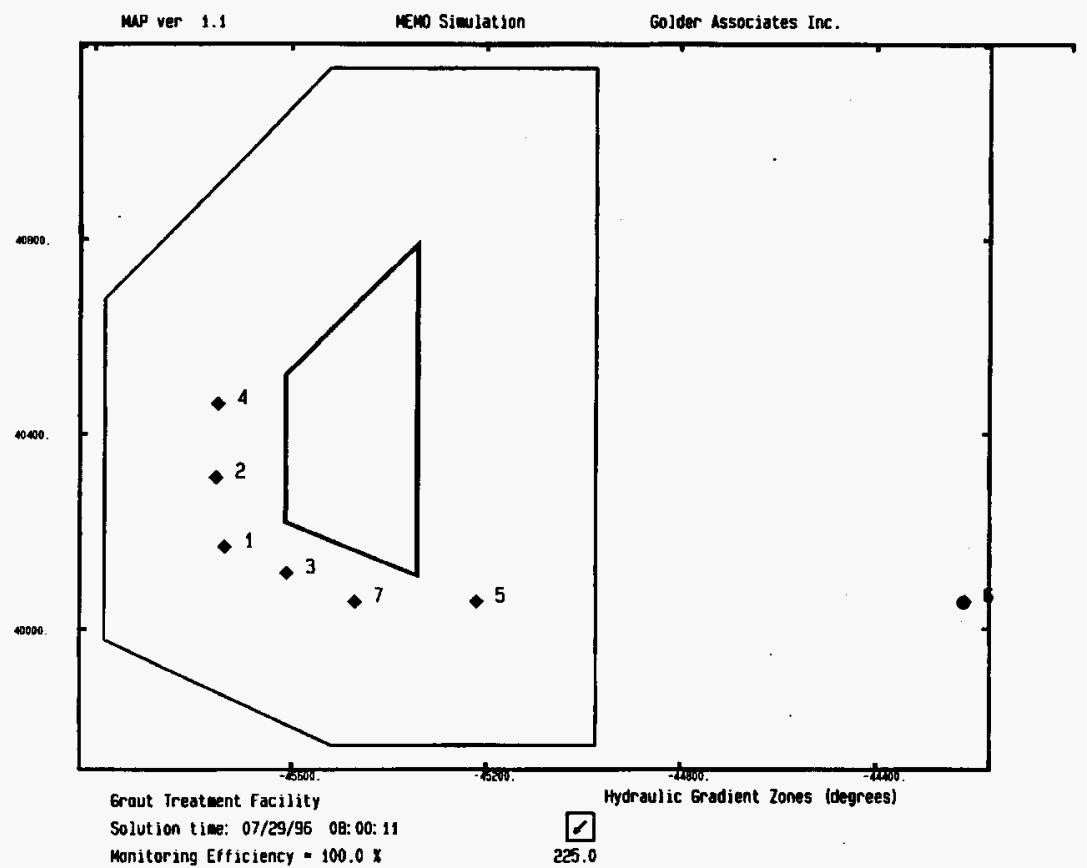



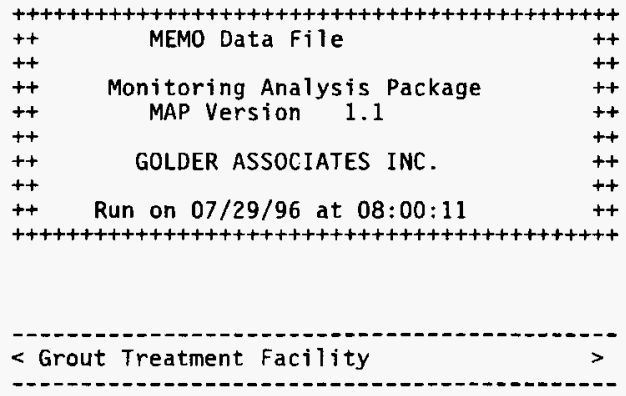

* SCALE factor 1.000000

* SOURCE GRID PARAMETERS ( $x 0, y 0$,grid spacing, max $x$ incr, max $y$ incr) $\begin{array}{lll}-45612.000000 & 40110.000000 & 15.000000\end{array}$

\section{6}

* POTENTIAL. SOURCE AREA COORDINATES (\#, $x, y$, unit $\#$ )

$\begin{array}{llll}1 & -45342.00 & 40110.00 & 1 \\ 2 & -45612.00 & 40220.00 & 1 \\ 3 & -45612.00 & 40520.00 & 1 \\ 4 & -45342.00 & 40790.00 & 1\end{array}$

* aRRAY SPACINg fOR bUFFER zONE coORdinates (max. spacing)

20.000000

- INPUT BUFFER ZONE COORDINATES $(\#, x, y)$

$\begin{array}{ccc}1 & -45520.00 & 41155.00 \\ 2 & -44974.00 & 41155.00 \\ 3 & -44974.00 & 39760.00 \\ 4 & -45520.00 & 39760.00 \\ 5 & -45980.00 & 39978.00 \\ 6 & -45980.00 & 40675.00 \\ { }^{6} & \text { MONITORING WELL COORDINATES }(\#, x, y) \\ 1 & -45735.00 & 40170.00 \\ 2 & -45753.00 & 40311.00 \\ 3 & -45609.00 & 40116.00 \\ 4 & -45749.00 & 40462.00 \\ 5 & -45219.00 & 40056.00 \\ 6 & -44219.00 & 40056.00 \\ 7 & -45469.00 & 40056.00\end{array}$
$5.260000 \mathrm{E}-02$
40.000000
28.000000
$0.000000 \mathrm{E}+00$
8.000000
$1.000000 \mathrm{E}-01$

* GRADIENT ZONE COORDINATES (\#, $x, y$, unit $\#$, angle)

$\begin{array}{ccccc}\text { * GRADIEN } & \text {-47000.00 } & 42000.00 & 1 & 225.00 \\ 2 & -43000.00 & 42000.00 & 1 & 225.00 \\ 3 & -43000.00 & 39000.00 & 1 & 225.00 \\ 4 & -47000.00 & 39000.00 & 1 & 225.00\end{array}$

* Solution Results

Maximum advection time $=36500.000000$

Accuracy of solution $=1.000000 \mathrm{E}-04$

Solution basis = buffer zone/advection time

Total \# of source points =

* of undetected leaks =

624 
WHC-SD-WM-ES-398 Rev. 0

This page intentionally left blank. 


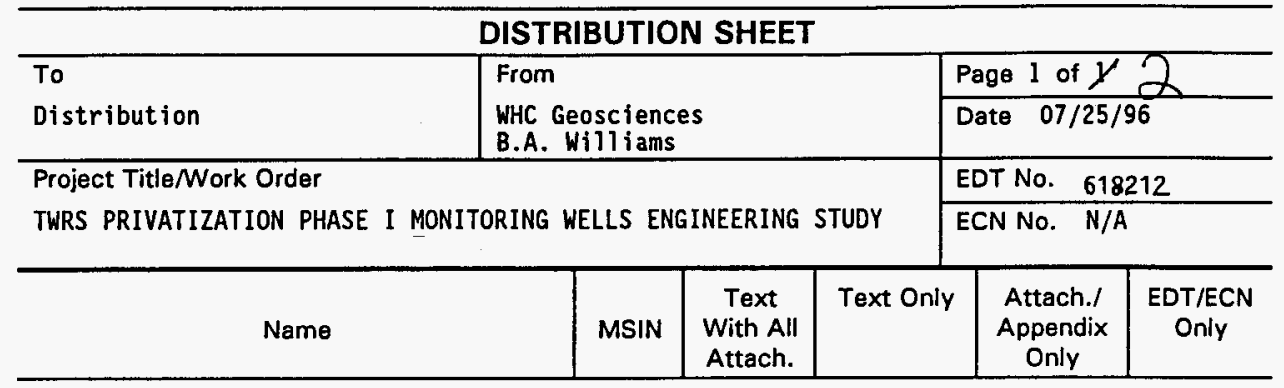

U.S. Department of Energy - Richland Operations Office
N. R. Brown
M. J. Elsen
K6-51
A2-45
M. J. Furman
T. R. Hoertkorn
W. A. Rutherford
$\mathrm{HO}-12$
B4-55
R3-25
R. B. Simmons-Green
S7 -53
$x$
$x$
$x$
$x$
$x$
$x$

Bechtel Hanford. Inc.
K. R. Fecht
H0-02
H0-17
G. B. Mitchem
$X$

$x$

IT Hanford. Ine.

G. L. Kasza

M. E. Todd

ICF Kaiser Hanferd Comouny

D. L. Fort

M. D. Rickenbach

E. T. Trost

E. F. Yancey

\section{Pacific Northwest National Laboratory}

M. Lerchen

S. P. Luttrell

B. A. Reynolds

W. D. Webber

Westinghouse Hanford Company

D. Alison

D. B. Barnett

J. W. Fassett

P. Felise

M. G. Gardner

J. S. Garfield

K. A. Gasper

D. G. Horton

M. N. Is Iam
H9-11

H9-11

$x$

$x$

G3-12

G3-12

G3-10

G3-10

$x$

$x$

$x$

$x$
K8-03

K6-96

P7-19

K6-96

R1-51

H6-06

H6- 06

B4-55

S3-24

H5-49

G3-21

H6-06

R3-08 $x$

$x$ 
Westinghouse Hanford Company (Continued)

J. G. Johnson

F. M. Mann

P. C. Miller

R. J. Parazin

S. M. Price

S. P. Reidel

J. A. Serkowski

A. L. Shord

D. E. Skoglie

W. R. Thackaberry

L. E. Thomas

J. A. Upshaw

J. M. Votava

B. A. Williams

M. T. York

EDMC (2)

Central Files (original + 1)
H6-06

H0-31

Rl-51

H5- 49

H6-23

H6-06

H6-06

H5-49

S3-24

H6-32

R3-08

S5-15

H6-06

H6-06

H6-29

H6-08

A3-88 $x$
$x$

X

X 